\title{
ENFORCING THE FEDERAL WATER RESOURCE SERVITUDE ON SUBMERGED AND RIPARIAN LANDS
}

\author{
BRUCE H. JOHNSON*
}

From the earliest years of this country's history, the federal courts have recognized the importance of American waterways in interstate and foreign commerce and have acknowledged that the power to regulate the use of water resources is included within the more general federal power to regulate commerce. ${ }^{1}$ Although most of the nation's submerged and tidal lands are owned by the states or by private individuals who derive their rights from the states, the federal government retains important powers to limit the use of such properties. Under the commerce clause, ${ }^{2}$ the government has the power to regulate and control many of the ways in which riparian lands can be used and developed. ${ }^{3}$ In effect, the people of the United States possess an inchoate easement guaranteeing use of the nation's water resources to persons engaged in activities related to commerce. Where Congress takes affirmative action, owners of riparian or submerged land may be obliged to refrain from activities which impair uses of the waters which inundate their property. Potentially, the rights protected by this easement are as varied as the number of commercial possibilities for the use of water. But it must be emphasized that the public may not enjoy any of its inchoate easement rights

* Assistant United States Attorney for the Eastern District of North Carolina. A.B. 1966, J.D. 1973, Duke University. The views expressed herein are strictly those of the author and do not necessarily reflect the views of the United States Department of Justice.

THE FOLLOWING CITATIONS WILL BE USED IN THIS ARTICLE:

Federal Water Pollution Control Act Amendments of 1972, Pub. L. No. 92-500, 86 Stat. 816 (codified at 33 U.S.C. $\S \S 1251$ et seq. (Supp. IV 1974))[hereinafter cited as FWPCA];

Rivers and Harbors Appropriation Act of 1890, Act of Sept. 19, 1890, ch. 907, §7, 26 Stat. 454 [hereinafter cited as 1890 Act];

Rivers and Harbors Appropriation Act of 1899, Act. of Mar. 3,1899, ch. 425, §§ 9-17, 19-20, 30 Stat. 1121 (codified at 33 U.S.C. $\$ \S 401,403-404,406-409,411,413-415$ (1970) [hereinafter cited as the $1899 \mathrm{Act}]$.

1. In Gibbons v. Ogden, 22 U.S. (9 Wheat.) 1, 190 (1824), Chief Justice Marshall noted the origins of the federal government's power to control activities which affect the flow of water transportation:

All America understands, and has uniformly understood, the word "commerce," to comprehend navigation. It was so understood, and must have been so understood, when the constitution was framed. The power over commerce, including navigation, was one of the primary objects for which the people of America adopted their government, and must have been contemplated in forming it.

2. U.S. CONST. art. I, § 8, cl. 3.

3. E.g., United States v. Appalachian Power Co., 311 U.S. 377, 426-27 (1940), quoted in text accompanying note 35 infra. See notes $26-53$ infra and accompanying text. 
until Congress has acted affirmatively to bring them into existence and to provide for their enforcement. ${ }^{4}$

To date, the method which Congress has customarily selected for giving substance to public water resource rights has been the enactment of federal restrictions on private activities in or around waters and adjacent wetlands. The substance of these restrictions has been widely discussed in both the academic community and the political arena. ${ }^{5}$ However, bringing inchoate rights into existence means little if those rights are not enforced. An easement owner is in no better position than a stranger to the burdened land if he cannot effectively prevent or abate inconsistent uses. Similarly, without an effective method of controlling inconsistent uses, the public's rights in the nation's water resources may have little practical value.

Unfortunately, enforcement of federal controls on water resource use is considerably more difficult and complex than the protection of rights under a conventional easement. An easement holder seeking relief in the courts is normally concerned only with vindication of his property rights. On the other hand, government efforts to protect water resource uses for the public embrace a nation-wide program involving a variety of geographical settings, policy considerations, equities and public interests. ${ }^{6}$ In the past, administrative and judicial enforcement proceedings have tended to resolve each enforcement case on an ad hoc basis. The danger with this approach is that it

4. See Willson v. Black-bird Creek Marsh Co., 27 U.S. (2 Pet.) 245, 252 (1829). There Chief Justice Marshall referred to the federal power to protect the public's right to unrestricted navigation as a power "in its dormant state" which did not affect state or private rights in the absence of express congressional legislation. The case involved the constitutionality of a Delaware statute which authorized the construction of a dam across a navigable stream. In holding that the statute was constitutional in the absence of federal legislation guaranteeing the right to navigate along such streams, the Supreme Court observed:

If congress had passed any act which bore upon the case; any act in execution of the power to regulate commerce, the object of which was to control state legislation over those small navigable creeks into which the tide flows, and which abound throughout the lower country of the middle and southern states; we should feel not much difficulty in saying, that a state law coming to conflict with such act would be void. Id.

5. See, e.g., House COMm. on Gov't Operations, Our Waters and Wetlands: How the Corps of Engineers Can Help Prevent Their Destruction and Pollution, H.R. Rep. No. 91-917, 91st Cong., 2d Sess. (1970); S. REp. No. 92-414, 92d Cong., 1st Sess. (1971)(FWPCA); S. REP. No. 92-1236, 92d Cong., 2d Sess. (Conf. Rep. 1972) (FWPCA); Kramon, Section 10 of the Rivers and Harbors Act: The Emergence of a New Protection for Tidal Marshes, 33 MD. L. Rev. 229 (1973); Teclaff, The Coastal Zone-Control over Encroachments into the Tidewaters, 1 J. MAR. L. \& COM. 241 (1970); Comment, The Federal Water Pollution Control Act Amendments of 1972, 14 B.C. INDUS. \& CoM. L. REv. 672 (1973).

6. Cf. United States v. Joseph G. Moretti, Inc., 526 F.2d 1306 (Sth Cir. 1976)(developer's dredging of canals affects the condition of navigable waters, subjecting developer to jurisdiction of Corps of Engineers). Where, however, the government is attempting to enforce its proprietary, as opposed to regulatory, easement rights, it appears to stand in the same position as a private landowner. See United States v. Sea Gate, Inc., 397 F. Supp. 1351 (E.D.N.C. 1975)(action to enforce rights under waterway easement acquired by express reservation). 
frequently produces different results in apparently similar cases and consequently undermines public confidence in the federal regulatory program as a whole. Recent developments indicate, however, that administrators and courts have begun to address this problem and have moved toward a more programmatic approach to enforcing federal water resource controls. After a general discussion of the restrictions which Congress has sought to impose on owners of submerged and riparian lands, this Article will examine some of the current developments in the federal enforcement effort and will seek to define the basic issues that seem likely to dominate future administrative and judicial enforcement proceedings.

\section{ThE GROWTH OF FEDERAL INTEREST IN REGULATING WATER RESOURCE USE}

Throughout the first hundred years of this country's history, watercourses were among the most important arteries of transportation. It is not surprising, therefore, that navigation was the first water resource use to be placed within the scope of federal regulation. Beginming in the early years of the nineteenth century, the inherent power of the national government to regulate activities which might interfere with the public's right to move freely along navigable waters was frequently acknowledged, ${ }^{7}$ but the courts also emphasized repeatedly that exercises of this power would not be implied and that affirmative action by Congress was necessary to place navigation under federal control. ${ }^{8}$ Congress was slow to accept this mandate and made no serious effort to regulate the navigability of the waters of the United States throughout most of the nineteenth century. ${ }^{9}$ During this period, the business of regulating activities that tended to obstruct the navigability of waters was left largely in the hands of the individual states. ${ }^{10}$ As late as 1888, the Supreme Court noted an absence of federal means to prevent even a serious obstruction to the navigation of a commercially important river. ${ }^{11}$

7. See, e.g., Gilman v. Philadelphia, 70 U.S. (3 Wall.) 713, 724-25 (1866); United States v. Coombs, 37 U.S. (12 Pet.) 72, 78 (1838). See also Gibbons v. Ogden, 22 U.S. (9 Wheat.) 1, 190 (1824). The relevant portion of the Gibbons opinion is quoted in note 1 supra.

8. See, e.g., Pound v. Turck, 95 U.S. 459, $462-64$ (1878) and cases cited therein. But cf. Illinois v. City of Milwaukee, 406 U.S. 91 (1972)(water pollution may be abated in an action based on federal common law nuisance even in the absence of congressional legislation).

9. All that existed were a few isolated legislative efforts such as the Northwest Ordinance of 1787 , which included a provision that streams which flowed into the Mississippi or St. Lawrence Rivers should be "common highways, and forever free." Northwest Ordinance of 1787, art. IV, 1 Stat. 52 (1789).

10. In the absence of legislation bringing dormant federal regulatory powers into existence, the states appear to have had full responsibility for regulating obstructions to navigation of water within their borders. E.g., Willamette Iron Bridge Co. v. Hatch, 125 U.S. 1, 12-13 (1888); Pound v. Turck, 95 U.S. 459, $462-64$ (1878).

11. Willamette Iron Bridge Co. v. Hatch, 125 U.S. 1, 12-13 (1888). 


\section{A. The Rivers and Harbors Appropriation Act of 1890}

Congress made its first attempt to establish plenary federal control over obstructions to navigability in the Rivers and Harbors Appropriation Act of $1890 . .^{12}$ The Act of 1890 prohibited, inter alia, "the creation of any obstruction, not affirmatively authorized by law, to the navigable capacity of any waters, in respect of which the United States has jurisdiction." 13 This was the first serious effort to exert federal control over the nation's waters for the purpose of reserving certain uses of those resources to the public. The approach to federal regulation embodied in the 1890 Act set the pattern for future legislation. Unlike previous efforts, which had sought to establish federal jurisdiction over specific bodies of water, the 1890 statute was directed toward the creation and protection of a public right of unrestricted navigation over any body of water susceptible to that use. ${ }^{14}$ The Act was designed to accomplish its objective by restricting activities that were inconsistent with navigability.

\section{B. The Rivers and Harbors Appropriation Act of 1899}

Less than a decade after the passage of the 1890 Act, Congress considered it necessary to legislate again. Through a flaw in draftsmanship, the 1890 Act had failed to establish plenary federal control over obstructions to navigation. ${ }^{15}$ Moreover, Congress perceived a need to consolidate under one statute all the existing federal law affecting the public's right to use the waters of the United States as highways of trade. ${ }^{16}$ The result was the

12. 1890 Act.

13. The 1890 Act provided in part:

[T] able capacity of any waters, in respect of which the United States has jurisdiction, is hereby prohibited. The continuance of any such obstruction, except bridges, piers, docks and wharves, and similar structures erected for business purposes, whether heretofore or hereafter created, shall constitute an offense and each week's conId. $\$ 10$.

tinuance of any such obstruction shall be deemed a separate offense.

14. In construing the 1890 Act in United States v. Rio Grande Dam \& Irrigation Co., 174 U.S. 690 (1899), the Supreme Court confirmed that the statute was concerned with uses and not simply federal control over territory. The action had been brought by the United States to restrain a private company from erecting a dam across an arguably non-navigable portion of the Rio Grande River. In reversing a dismissal by the lower courts, the Court indicated that the issue in the case was not whether the dam was being built across a navigable portion of the river but whether construction would diminish the navigable capacity of any part. Id. at 707-08.

15. The problem resulted from the phrase "any obstruction, not affirmatively authorized by law," which the Supreme Court construed to mean that obstructions authorized by state law were excluded from the 1890 Act's prohibition. United States v. Bellingham Bay Boom Co., 176 U.S. 211 (1900).

16. The Rivers and Harbors Appropriation Act of 1892, Act of July 13, 1892, ch. 158, $\$ 3$, 27 Stat. 110, had amended the 1890 Act by prohibiting three additional activities: (1) the erection of obstructions to navigation; (2) the erection of bridges over navigable waters without prior authorization from the Secretary of War; and (3) the unauthorized modification of channels. Four years later, in the Rivers and Harbors Appropriation Act of 1896, Congress directed the 
enactment of twelve sections in the Rivers and Harbors Appropriation Act of 1899 establishing various federal controls over the use of navigable waters. ${ }^{17}$ Perhaps the most important provision of the 1899 Act is section $10,{ }^{18}$ which is functionally analogous to the earlier 1890 Act. ${ }^{19}$ Both create federal controls over the nation's waters for transportation purposes, and both have provisions directed against activities tending to diminish navigability. ${ }^{20}$ There is one important difference, however: while the 1890 Act was directed entirely against obstructive activities, ${ }^{21}$ section 10 of the 1899 Act extends regulation to activities which may arguably enhance navigability. ${ }^{22}$

The practical effect of the Rivers and Harbors Appropriation Act of 1899 is to encumber state and private ownership of submerged and riparian lands with a rather complex federal easement for navigation. This easement operates affirmatively to preserve the right of unrestricted passage over all navigable waters, except where impediments to navigation are expressly authorized by Congress. As such, it also restricts the property rights of owners of land which underlies or adjoins navigable waters. The 1899 Act empowers the federal government to regulate, prevent or even abate state or private activities which tend to make navigable or potentially navigable waters either less or more desirable for navigation. ${ }^{23}$ The Act also reaches activities on "dry land" and in non-navigable waters which may ultimately affect the capacity of navigable waters. ${ }^{24}$

Ostensibly, the 1899 Act was only intended to protect and facilitate navigation, and early court decisions tended to support this view. ${ }^{25}$ The

Secretary of War to make a survey of federal laws relating to navigation and to propose a comprehensive statute on the subject. Act of June 3, 1896, ch. 314, \& 2, 29 Stat. 234. See generally A. Reitze, Environmental Planning: LAW of LAND and Resources Two-23 through Two-24 (1974) (discussion of the problem of consolidation faced by Congress).

17. 1899 Act.

18. Id. $\S 10$ (codified at 33 U.S.C. $\S 403$ (1970)). See note 55 infra for the text of this section.

19. See note 13 supra for a partial text of the 1890 Act.

20. Compare 1890 Act, quoted in note 13 supra, with 1899 Act $\$ 10,33$ U.S.C. $\$ 403$ (1970), quoted in note 55 infra.

21. See note 13 supra and accompaning text.

22. Section 10 of the 1899 Act actually has three separate operative provisions. See 1899 Act $\$ 10,33$ U.S.C. $\$ 403$ (1970); see also the discussion in notes 55-70 infra and accompanying text. The third of these prohibits the alteration or modification of any navigable body of water and may be applied even where a waterway's navigable capacity is actually enhanced. See notes 63-64 infra and accompanying text.

23. See notes 65-69 infra and accompanying text for a discussion of the term "navigable water" as it is used in the 1899 Act.

24. 1899 Act $\S 13,33$ U.S.C. $\S 407$ (1970) prohibits, inter alia, the placement of refuse material "on the bank of any navigable water, or on the bank of any tributary of any navigable water" where the material is apt to be introduced into the water so as to impede or obstruct navigation.

25. In United States v. Banister Realty Co., 155 F. 583 (C.C.E.D.N.Y. 1907), for example, it was clearly suggested that the 1899 Act could only be invoked to regulate activities in waters which were actually being used for navigation: 
Supreme Court, however, has adopted a somewhat broader interpretation of the Act's coverage. In Sanitary District $v$. United States, ${ }^{26}$ the Court held that navigable capacity, and not merely navigation itself, was the object of federal control. ${ }^{27}$ While this did not suggest that the 1899 Act could be used for any purpose other than the control of navigability, within the following decade, dicta from three Supreme Court cases indicated that there might be additional dimensions to the regulatory powers created by the Act. In New Jersey v. Sargent ${ }^{28}$ and Arizona v. California ${ }^{29}$ the Court clearly implied that once some connection between an activity and navigability had been established, the federal government's regulatory power came into play and could then be exercised to accomplish federal objectives which had nothing to do with navigation. ${ }^{30}$ This suggestion was reiterated with particular clarity in United States ex rel. Greathouse v. Dern, ${ }^{31}$ where the Court implied that it was entirely proper for the Secretary of War to refuse to authorize construction of a wharf on land which the United States was about

It has been frequently held that the admiralty jurisdiction of the United States attaches to all such bodies of water . . ., and this admiralty jurisdiction can be lost only when the particular water loses the character of a stream capable of carrying on interstate commerce or of navigation in and out from the ocean for pleasure and business purposes. Under this construction, Far Rockaway Bay, unless it has so lost the character of navigability as to be outside of the admiralty and maritime jurisdiction of the United States courts, is subject to the provisions and regulations of the act of 1890 , as amended by the acts of 1892,1899 and 1900 .

Id. at 595. The case involved an action for an injunction to restrain riparian property owners from closing an inlet. A preliminary injunction was entered pending adjudication of the issue of whether the bay in question had lost its navigable character.

26. 266 U.S. 405 (1925).

27. In upholding the right of the United States to bring an action enjoining a state agency from diverting water from Lake Michigan, the Court explained that "a withdrawal of water on the scale directed by the statute of Illinois threatens and will affect the level of the Lakes, and that is a matter which cannot be done without the consent of the United States . . . ." Id. at 426.

28. 269 U.S. 328 (1926).

29. 283 U.S. 423 (1931).

30. New Jersey v. Sargent, 269 U.S. 328 (1926), was an action by the State of New Jersey for a declaratory judgment that certain portions of the Federal Water Power Act were unconstitutional. The Supreme Court dismissed the case for failure to state a "case or controversy." Id. at 339-40. In dicta, however, the Court implied that the Act's purpose of establishing federal control over the production of hydroelectric power could be accomplished pursuant to Congress' constitutionally vested power to regulate activities in navigable waters. Id. at 337 .

Arizona v. California, 283 U.S. 423 (1931), involved a controversy over the construction of a dam across the Colorado river; the dam was to be built primarily for irrigation purposes. In considering the federal government's authority to construct the dam, the Court relied on the power to regulate navigability:

Since the grant of authority to build the dam and reservoir is valid as an exercise of the Constitutional power to improve navigation, we have no occasion to decide whether the authority to construct the dam and reservoir might not also have been constitutionally conferred for the specified purpose of irrigating public lands of the United States.

Id. at 457 (footnote omitted).

31. 289 U.S. 352 (1933). 
to condemn. Although the structure technically affected navigation, the real source of the government's concern was that its presence would tend to increase the cost of condemnation. ${ }^{32}$ Dern was actually decided on other grounds, ${ }^{33}$ but it represents the first indication that the 1899 Act might be used as an instrument for accomplishing a variety of federal objectives in addition to those related to navigability.

The implication left by the Dern case and its predecessors was that if even a de minimis connection could be established between an activity and the navigability of some body of water, the activity was subject to federal control and could be regulated for any valid national purpose. If the Secretary of War could withhold authorization to build a wharf because its construction would increase government condemnation costs, it would appear that he could also seek removal of an existing but unauthorized wharf because its presence would impair the land's future value as a public park. In United States v. Appalachian Electric Power Co. ${ }^{34}$ the Supreme Court expressed what had previously been only implicit:

In our view, it cannot properly be said that the constitutional power of the United States over its waters is limited to control for navigation. ... In truth the authority of the United States is the regulation of commerce on its waters. Navigability, in the sense just stated, is but a part of this whole. . . . The point is that navigable waters are subject to national planning and control in the broad regulation of commerce granted the Federal Government. ${ }^{35}$

Clearly, this interpretation of the 1899 Act impresses a broad federal easement upon submerged and riparian lands. Nevertheless, many years passed before the federal government began actively to invoke the Rivers and Harbors Appropriation Act of 1899 to control the use of waters and inundated lands for purposes essentially unrelated to navigation. During the three decades following the Dern case, the United States Army Corps of Engineers, the federal agency with responsibility for administering the 1899 Act, remained concerned primarily with protecting the nation's interest in navigability, and its administrative permit regulations were directed almost exclusively toward this end. ${ }^{36}$ Similarly, litigation initiated under the 1899

32. See id. at $355-56$.

33. The action was brought for a writ of mandamus to compel the Secretary of War to issue a permit under section 10 of the 1899 Act, 33 U.S.C. $\$ 403$ (1970), for the construction of a wharf which would extend into the Potomac River from property located within the proposed site for the George Washington Memorial Parkway. The lower court denied the writ on the ground that issuing a permit was not a "ministerial act" and, therefore, that mandamus did not lie. 63 F.2d 137, 141-42 (D.C. Cir. 1933). The Supreme Court affirmed on the rationale that the potential vindication of petitioners' asserted rights was offset by the harm to the public interest that the requested relief would surely bring. 289 U.S. at 359-60.

34. 311 U.S. 377 (1940).

35. Id. at $426-27$.

36. See Corps of Engineers, Department of the Army, Permits for Work in Navig- 
Act was directed almost entirely toward the prevention and abatement of obstructions to navigation. ${ }^{37}$.

\section{Environmental Enforcement Under the Commerce Clause}

The congressional passage of the Fish and Wildlife Coordination Act Amendments of $1958^{38}$ marked the beginning of a new effort by the federal government to include environmental considerations, such as the protection of fish and wildlife, in the planning of water resource projects. Originally, it was uncertain whether the 1958 Amendments were intended to apply to state and private projects requiring any kind of federal license or only to projects sponsored by governmental or quasi-governmental bodies. ${ }^{39}$ Nevertheless, a broad view of the Amendments' applicability had clearly taken hold by 1967 when the Secretary of the Army and the Secretary of the Interior entered into a Memorandum of Understanding delineating the responsibilities of their respective agencies under the Fish and Wildlife Coordination Act. ${ }^{40}$ The agreement provided that all inter-agency communications concerning Department of the Army permit applications would be between the appropriate District Engineers and Regional Directors of the Fish and Wildlife Service. $^{41}$ To promote harmony and cooperation between the two departments,

ABLE WATERS 2 (1962) ("' $[t]$ he decision as to whether a permit will be issued must rest primarily upon the effect of the proposed work on navigation").

37. See, e.g. , United States v. Republic Steel Corp., 155 F. Supp. 442 (N.D. Ill. 1957), rev'd and vacated, 264 F.2d 289 (7th Cir. 1959), rev'd, 362 U.S. 482 (1960). The case involved a discharge of industrial solid wastes into the Calumet River; nevcrtheless, the controversy was focused solely on the issue of navigability. See also United States v. Perma Paving Co., 332 F.2d 754 (2d Cir. 1964); United States v. New York Cent. R.R., 252 F. Supp. 508 (D. Mass. 1965) aff'd per curiam, 358 F.2d 747 (1st Cir. 1966).

38. Pub. L. No. 85-624, § 2, 72 Stat. 564, 16 U.S.C. §§ 662(a)-(b) (1970) (amending 16 U. S.C. $\S 662$ (1952)). The original Fish and Wildlife Coordination Act was passed by Congress on March 10, 1934. See Pub. L. No. 73-121, § 1, 48 Stat. 401. In substance, it had provided that where it was not inconsistent with the primary use of a federal water impoundment project, the federal fish and wildlife agencies should be given the opportunity to use the impoundment for fish culture stations and migratory bird resting places. Id. The 1958 Amendments required that the U.S. Fish and Wildlife Service be consulted in connection with any federal project or permit having the effect of modifying any stream or body of water. 16 U.S.C. $\S 662(b)(1970)$. In addition to directing these consultations, the Amendments also require the Secretary of the Intcrior to make a report and recommendations concerning wildlife. These reports are based upon the surveys and investigations by the Fish and Wildlife Service. See id. It should be noted, however, that the Fish and Wildlife Coordination Act, as amended, does not give any sort of veto power to either the Fish and Wildlife Service or to the Secretary of the Interior. Their roles are strictly advisory, and the agency constructing or permitting the water resource project is free to disregard their advice. See A. ReITZE, supra note 16, at Two-51 through Two-59 for a useful general discussion of the 1958 Amendments to the Fish and Wildlife Coordination Act.

39. See A. REITZE, supra note 16, at Two-34 through Two-35. See also id. at Two-51 through Two-53.

40. The text of the Memorandum of Understanding is set forth at 33 C.F.R. $\S 209.129$, App. B (1976).

41. See id. § 290.120, App. B, Policy 1, at 393. 
the Secretary of the Army also agreed that no District Engineer would be allowed to issue a Department of the Army permit under the 1899 Act over the official objections of the appropriate Regional Director of the Fish and Wildlife Service. ${ }^{42}$ If disputes arose, they would be forwarded through appropriate channels to the offices of the two Secretaries for resolution. ${ }^{43}$ More recently, a formalized procedure for eliciting Interior Department views on prospective or pending litigation in connection with violations of the 1899 Act has also been established. ${ }^{44}$

In the year following the adoption of the Memorandum of Understanding, the Corps of Engineers amended its regulations to require a "public interest review" of all applications for permits under the $1899 \mathrm{Act}^{45}$ In substance, these regulations provide that consideration of a Department of the Army permit application includes not only an examination of the proposed activity's impact on navigability but also an evaluation of the activity's effect on any other aspect of the public interest. ${ }^{46}$ Federal attention had thus begun to focus on the regulatory powers suggested by Dern and its companions. ${ }^{47}$

The broad scope of these regulatory powers soon became evident. Zabel v. Tabb ${ }^{48}$ was the first major decision which upheld the Corps of Engineers' authority to rely solely on ecological grounds in denying a private landowner's application for an 1899 Act permit for work in navigable waters:

The starting point here is the Commerce Clause and its expansive reach. The test for determining whether Congress has the power to

42. See id., Procedure 4, at 394.

43. Id., Procedures 4-7, at 394. See also Conservation Council v. Costanzo, 398 F. Supp. 653 (E.D.N.C.), aff'd 528 F.2d 250 (4th Cir. 1975). In a suit to enjoin the issuance of a Department of the Army permit to a private developer, one of the grounds for relief asserted by the conservation organization was an alleged violation of the Memorandum of Understanding. Although the District Court found the possibility of internal irregularities within the Department of the Interior, it concluded that no interagency disagreement had arisen and, therefore, that the "disputes provision" of the Memorandum had never come into play. 398 F. Supp. at 665-66, 673.

44. 33 C.F.R. $\S 209.120(\mathrm{~g})$ (12)(ii) (1976). The current format for consultations between the Corps of Engineers and the Fish and Wildlife Service on violations occurring in the Eastern District of North Carolina is discussed in notes 102-105 infra and accompanying text.

45. 33 C.F.R. $\$ 209.120(f)(1)$ (1968).

46. Other aspects of the public interest include the effect of the proposed work on navigation, fish and wildlife, conservation, pollution, esthetics, ecology and the general public interest. Id.

47. This shift in the government's attention reflected growing public concern over intensifying pressures to develop the nation's natural resources, including its waterways and wetlands. This concern was recognized in Congress which articulated a national policy aimed at restoring and preserving the natural condition of those areas. See, e.g., National Estuary Protection Act, 16 U.S.C. $\$ 1221$ (1970); Water Bank Act, 16 U.S.C. § 1301 (1970); FWPCA, 33 U.S.C. § 1251 (Supp. IV 1974).

48. 430 F.2d 199 (5th Cir. 1970), cert. denied, 401 U.S. 910 (1971). 
protect wildlife in navigable waters and thereby to regulate the use of private property for this reason is whether there is a basis for the Congressional judgment that the activity regulated has a substantial effect on interstate commerce. That this activity meets this test is hardly questioned. In this time of awakening to the reality that we cannot continue to despoil our environment and yet exist, the nation knows, if Courts do not, that the destruction of fish and wildlife in our estuarine waters does have a substantial, and in some areas a devastating, effect on interstate commerce. ${ }^{49}$

Other courts have generally accepted Zabel as a correct interpretation of the scope of federal regulatory powers under the Rivers and Harbors Appropriation Act of $1899 .^{50}$ The proposition now seems firmly established that if a connection can be shown between a private owner's use of submerged or tidal lands and navigability, the federal government has the right to control, prevent or abate that use in order to accomplish any national purpose which is within the scope of its powers under the commerce clause. Moreover, if one accepts the dictum in United States ex rel. Greathouse v. Dern as law, federal control of private uses can be exercised not only to promote commerce but to accomplish any purpose within the scope of the constitutional powers conferred on the national government.

\section{The Federal Water Pollution Control Amendments of 1972 (FWPCA)}

In its 1972 amendments to the Federal Water Pollution Control Act, ${ }^{51}$ Congress acted once again to reify inchoate public rights in the nation's water resources. The stated purpose of the Federal Water Pollution Control Act Amendments of 1972 is to create a public right to use water in a physically, chemically and biologically pristine form. ${ }^{52}$ To accomplish this purpose, the operative provisions of the FWPCA grant executive agencies the power to regulate certain private activities affecting water quality. ${ }^{53}$

The regulatory approach embodied in the FWPCA follows the pattern of earlier legislation: the statute attempts to preserve the public's rights by.

49. 430 F.2d at 203-04 (citations omitted).

50. E.g., Sierra Club v. Morton, 400 F. Supp. 610, 635 (N.D. Cal. 1975); United States v. Cannon, 363 F. Supp. 1045, 1051 (D. Del. 1973); United States v. Lewis, 355 F. Supp. 1132, 1134 (S.D. Ga. 1973); United States v. Underwood, 344 F. Supp. 486, 489 (M.D. Fla. 1972).

51. FWPCA.

52. Id. § 101(a), 33 U.S.C. \$1251 (Supp. IV 1974).

53. The primary operative provision of the FWPCA is section 301(a), 33 U.S.C. § 1311(a)(Supp. IV 1974) which, with certain statutory exceptions, makes the discharge of any pollutant unlawful. For a discussion of how section 301(a) ultimately acts to restrict private activities in or around the waters of the United States, see notes 73-79 infra and accompanying text. In essence, 33 U.S.C. $\$ \S 1311$ (b)-(f), 1312, 1316, 1317, 1328, 1342 and 1344 (1970) establish administrative permit programs through which otherwise unlawful discharges may be authorized. 
regulating private activities and uses rather than asserting federal jurisdiction over territory. But the scope of the use controls created by the FWPCA is potentially much broader than the scope of those created by the 1899 Act, since both the range and number of activities affecting water quality are far more extensive than those affecting navigability. So far, there has been no attempt by the federal government to use the FWPCA for any purpose other than the control of water quality; but should the dimensions of regulatory power under this statute be viewed as analogous to those under the 1899 Act, the FWPCA could become a powerful instrument for more general national planning.

\section{Restrictions on Private Activities AND Uses Created BY THE RIVERS AND HARBORS APPROPRIATION ACT OF 1899 AND THE FWPCA}

The Rivers and Harbors Appropriation Act of 1899 protects the public's right to unimpeded passage over the nation's watercourses, and the FWPCA is directed toward keeping the waters of the United States free of pollutants. Both statutes attempt to accomplish their respective ends by regulating other activities that are inconsistent with the stated national objectives. Since most, if not all, inconsistent activities are likely to occur on submerged and riparian lands, the two acts effectively burden those lands with negative or restrictive easements. This inquiry will next explore the extent to which these easements restrict or control private land and water resource use.

\section{A. Use Restrictions Under the 1899 Act and the Refuse Act}

While each of the provisions of the Rivers and Harbors Appropriation Act of 1899 restricts the private use of submerged and tidal lands to some extent, the most important sections of the Act (and those that form the basis for the most litigation) are sections 10 and $13 .{ }^{54}$ Section 10 actually contains three separate restrictions. ${ }^{55}$ The first forbids the creation of any obstruction

54. 1899 Act $\S \S 10,13,33$ U.S.C. $\S \S 403$ and 407 (1970), respectively.

55. 33 U.S.C. $\$ 403$ (1970) provides as follows:

The creation of any obstruction not affirmatively authorized by Congress, to the navigable capacity of any of the waters of the United States is prohibited; and it shall not be lawful to build or commence the building of any wharf, pier, dolphin, boom, weir, breakwater, bulkhead, jetty, or other structures in any port, roadstead, haven, harbor, canal, navigable river, or other water of the United States, outside established harbor lines, or where no harbor lines have been established, except on plans recommended by the Chief of Engineers and authorized by the Secretary of the Army; and it shall not be lawful to excavate or fill, or in any manner to alter or modify the course, location, condition, or capacity of, any port, roadstead, haven, harbor, canal, lake, harbor or refuge, or inclosure within the limits of any breakwater, or of the channel of any navigable water of the United States, unless the work has been recommended by the Chief of Engineers and authorized by the Secretary of the Army prior to beginning the same.

The Secretary of the Army has delegated his regulatory responsibilities under section 10 to the 
to the navigable capacity of any American waters without the affirmative authorization of Congress. ${ }^{56}$ The second portion of section 10 is somewhat more specific; it prohibits the placing of structures in any "water of the United States" without prior authorization from the Chief of Engineers and the Secretary of the Army. ${ }^{57}$ Neither of these provisions contains an express limitation on the waters which are subject to federal protection; they appear to apply with equal force to both navigable and non-navigable waters. One qualification, however, has generally been considered implicit in the prohibition against obstructions: the affected body of water should have reasonable potential for navigation. ${ }^{58}$ Otherwise, therc would be no "obstruction" in any real sense. Given the requisite demand and the appropriate technology, any body of water could conceivably become navigable, but the traditional approach has been to confine the prohibition against obstructions to waters which fall within three classes: waters which are presently navigable; waters which were once but are no longer navigated; and waters which foreseeably might be used for navigation in the future. ${ }^{59}$

There are also practical limitations on the restriction against obstructions to navigation. Ostensibly, an obstructive activity could be located anywhere; in theory, the government would only have to show that the activity either directly or indirectly affected the navigable capacity of some body of water in order to secure its abatement. ${ }^{60}$ The realities of administration and enforcement, however, effectively prohibit the government from seeking the abatement of technically obstructive activities where the work being performed is geographically remote from the affected body of water or where the effect on navigation is imperceptible. ${ }^{61}$ Similarly, while the 1899

Chief of Engineers. See 33 C.F.R. $\$ 209.120$, App. D (1976). The Chief of Engineers, in turn, has delegated many of his regulatory responsibilities to local District Engineers. See e.g., id. $\$$ 209.120(f).

56. See 33 U.S.C. $\S 403$ (1970), quoted in note 55 supra. For a discussion of the historical development of the prohibition against obstructions, see notes 12-22 supra and accompanying text.

57. 33 U.S.C. $\$ 403(1970)$.

58. See United States v. Appalachian Elec. Power Co., 311 U.S. 377, 404-10 (1940); United States v. Joseph G. Moretti, Inc., 478 F.2d 418, 428 n.36 (5th Cir. 1973). For further discussion of "navigability" under the 1899 Act, see notes 65-69 infra and accompanying text.

59. E.g., Rochester Gas \& Elec. Corp. v. FPC, 344 F.2d 594, 596 (2d Cir.), cert. denied, 382 U.S. 832 (1965); United States v. Crow, Pope \& Land Enterprises, Inc., 340 F. Supp. 25, 34 (N.D. Ga. 1972), appeal dismissed, 474 F.2d 200 (5th Cir. 1973); see United Statcs v. Granite State Packing Co., 343 F. Supp. 57, 60-61 (D.N.H. 1972)("'a river navigable in the past remains so in perpetuity so far as the power of Congress is concerned"), aff'd, $470 \mathrm{~F} .2 \mathrm{~d} 303$ (1st Cir. 1972).

60. See, e.g. United States v. Republic Steel Corp., 362 U.S. 482 (1960); Sanitary Dist. v. United States, 266 U.S. 405 (1925). For an example under the earlier 1890 Act, see United States v. Rio Grande Dam \& Irrigation Co., 174 U.S. 690 (1899), discussed in note 14 supra.

61. In its latest regulations implementing FWPCA § 404, 33 U.S.C. \$ 1344 (Supp. IV 1974), the Army Corps of Engineers has indicated that it will be asserting jurisdiction over certain activities in non-navigable bodies of water which affect water quality. See 33 C.F.R. $\S \S$ 
Act's prohibition of structures is not expressly confined to navigable waters, there has traditionally been very little federal interest in regulating structures in non-navigable bodies of water. ${ }^{62}$

The third prohibition contained in section 10 is the most general of all: it forbids the alteration or modification of the "course, location, condition, or capacity" of any navigable water. ${ }^{63}$ In proscribing obstructions and unauthorized structures, the first two provisions were clearly directed against activities which have an adverse effect on public navigation. The third provision, on the other hand, is not expressly confined to alterations or modifications which diminish navigable capacity. Even activities which arguably enhance navigability, such as digging canals or boat basins, ${ }^{64}$ are proscribed unless prior federal authorization has been obtained. The analogy of an easement is almost inapposite to this third portion of section 10 because the owner of burdened land normally has a right to uses which are at least consistent with those of the easement holder.

In another respect, however, the prohibition against unauthorized modifications is somewhat more limited than the restrictions contained elsewhere in section 10 . In order for federal regulatory jurisdiction to attach, an altered or modified body of water must be navigable. The Rivers and Harbors Appropriation Act of 1899 does not define the term "navigable," but in implementing the Act the Corps of Engineers has adopted its own definition: "Navigable waters of the United States are those waters which are presently, or have been in the past, or may be in the future susceptible of use for purposes of interstate or foreign commerce." 65 This administrative

209.120(d)(2)(h),(i) (1976). This expansion of the Corps' regulatory activities may result in increased interest in the control of less obvious obstructive activities which violate section 10 of the 1899 Act.

62. See notes 35-36 supra and accompanying text. In addition to the government's policy orientation, there are also several legal considerations which tend to diminish agency interest in using the 1899 Act to regulate structures in unnavigable waters. The single most effective way of dealing with most unauthorized structures is to initiate civil proceedings for a mandatory injunction compelling removal. But injunctions are equitable remedies which normally require some showing of irreparable harm. See notes 191-95, 209-11 infra and accompanying text. Piers or other small structures in non-navigable waters would not appear to impede the flow of waterborne commerce, and it can rarely be shown that they have an adverse effect on water quality or other aspects of the environment. If a pressing need for removal cannot be shown, it may be difficult to obtain equitable relief in the courts to enforce administrative control of such structures. But see United States v. Venters, Civ. No. 986 (E.D.N.C. June 26, 1974), discussed at note 190 infra and accompanying text.

63. 1899 Act $\S 10,33$ U.S.C. \$ 403 (1970).

64. See, e.g., Weiszmann v. District Eng'r, 7 E.R.C. 1523 (S.D. Fla. 1975), rev'd and remanded on other grounds, 526 F.2d 1302 (5th Cir. 1976). The Rivers and Harbors Appropriation Act of 1896 probably formed the basis for this third portion of section 10. See Act of June 3,1896 , ch. $314, \S 2,29$ Stat. 202, 234, discussed in note 16 supra.

65. 33 C.F.R. $\S 209.260$ (c) (1976). Compare the text accompanying notes 58-59 supra, which discusses the non-statutory navigability requirements traditionally imposed under section 10 's obstruction provision. 
definition of navigable waters is based on existing case law ${ }^{66}$ and has generally been accorded considerable deference by the courts ${ }^{67}$ Most courts have also accepted the Corps of Engineers' view that a tidal body of water is navigable up to its mean high water mark and that a non-tidal body of water is navigable up to its ordinary high water mark. ${ }^{68}$ There is, of course, nothing magic about the mean and ordinary high water marks, and arguments could be made that navigability extends beyond these somewhat arbitrary boundaries. ${ }^{69}$ But from a practical standpoint, more would be lost by abandoning these tests than might be gained in additional jurisdiction. Both of these water levels are relatively easy to prove, and, if there were no such convenient line of demarcation both for showing jurisdiction over an activity and for establishing a limit on remedial work, enforcement litigation would become considerably more complicated and concomitantly less effective. ${ }^{70}$

66. The Corps' three-prong test comports substantially with the test formulated by the Second Circuit in Rochester Gas \& Elec. Corp. v. FPC, 344 F.2d 594, 596, cert. denied, 382 U.S. 832 (1965). Various aspects of the Corps of Engineers' definition of navigable waters have been considered by other courts on numerous occasions. An excellent discussion of the concept of navigable waters under the 1899 Act can be found in Kramon, supra note 5, at 237-46 (1973).

67. See, e.g., United States v. Pot-Nets, Inc., 363 F. Supp. 812, 815 (D. Del. 1973). See also Kramon, supra note 5, at 233-34, 238.

68. See United States v. Pot-Nets, Inc., 363 F. Supp. 812, 815-16 (D. Del. 1973); United States v. Cannon, 363 F. Supp. 1045, 1049-51 (D. Del. 1973); United States v. Lewis, 355 F. Supp. 1132, 1137 (S.D. Ga. 1973). On the Pacific coast, the Corps of Engineers considers the limit of navigable waters to be the mean higher high water mark. 33 C.F.R. $\$ 209.260$ (k)(l)(ii) (1976). This also has received judicial approval. Sierra Club v. Leslie Salt Co., 412 F. Supp. 1096 (N.D. Cal. 1976). Without referring specifically to the Corps of Engineers' regulations, several other courts have accepted the mean or ordinary high water mark as the shoreward limit of federal jurisdiction under the Rivers and Harbors Appropriation Act of 1899. See United States v. Smith, 7 E.R.C. 1937 (E.D. Va. 1975); Weiszmann v. District Eng'r, 7 E.R.C. 1523,1525 (S.D. Fla. 1975), rev'd and remanded on other grounds, 526 F.2d 1302 (5th Cir. 1976); United States v. Stoeco Homes, Inc., 359 F. Supp. 672, 676 (D.N.J. 1973), vacated and remanded on other grounds, 498 F.2d 597 (3d Cir. 1974); United States v. Joseph G. Moretti, Inc., 331 F. Supp. 151, 158 (S.D. Fla. 1971), vacated and remanded on other grottnds, 478 F.2d 418 (5th Cir. 1973).

69. See United States v. Sexton Cove Estates, Inc., 526 F.2d 1293, 1296-97 (5th Cir. 1976).

70. For example, assume that the government brings an action under the 1899 Act to obtain removal of an unauthorized fill project which extends out into the water from clearly "dry" land. Initially, the government faces the problem of proving that the project is being built in "navigable waters" in order to show liability. Navigability is a factual question. See Crowell v. Benson, 285 U.S. 22, 55 (1932); Arizona v. California, 283 U.S. 423, 452 (1931). Having the mean high water mark as a convenient line of demarcation simplifies and limits the evidence which the government will have to offer to show liability. Jurisdiction and, therefore, liability can be established by showing that any part of the project extends waterward of the mean high water. The precise location of the mean high water mark, however, will normally have to be established in order to obtain a mandatory injunction compelling removal of the fill. The court must have some way of knowing how much of the fill material to order the defendant to remove. Without some simplifying device, such as the mean high water mark, establishing a limit on remedial work could become a difficult task, if not an impossible one. See the discussion in note 185 infra and accompanying text. 
Section 13 of the Rivers and Harbors Appropriation Act of 1899, commonly known as the Refuse Act, forbids the placement of refuse material in any one of three places: (1) in navigable waters of the United States; (2) in any tributary of navigable waters from which refuse may float or be washed into such navigable water; and (3) "on the bank of any navigable water, or on the bank of any tributary of any navigable water," where refuse will be liable to be washed into the navigable water, "either by ordinary or high tides, or by storms or floods." "71 Unlike the somewhat general provisions of section 10, the Refuse Act is quite specific both as to the nature of the activities which are subject to regulation and as to the territory in which regulated activites might take place. Unanswered questions concerning jurisdiction under the Refuse Act have largely been rendered moot by passage of the FWPCA. ${ }^{72}$

\section{B. Use Restrictions Under the FWPCA}

The Federal Water Pollution Control Act Amendments of $1972^{73}$ create still another instrument for federal control of private activities in the nation's waters and wetlands. Under section 301(a) of the FWPCA, it is unlawful to "discharge any pollutant" unless the discharge has been authorized under one of several permit programs established in other sections of the Act. ${ }^{74}$ It is not immediately obvious from section 301(a) that the statute is directed against water pollution, but the term "discharge of a pollutant" is defined by another provision as "any addition of any pollutant to navigable waters from any point source ...."75 The Act defines the term "navigable

71. 1899 Act $\$ 13,33$ U.S.C. $\S 407$ (1970).

72. One potentially troublesome jurisdictional question under the Refuse Act was raised in United States v. United States Steel Corp., 482 F.2d 439 (7th Cir.), cert. denied, 414 U.S. 909 (1973), in which the defendant argued that it was necessary for the government to show that a discharge actually impeded or obstructed navigation before it could be forbidden by section 13 . The court of appeals disagreed, holding that " $[t]$ he discharge of any refuse matter, regardless of any apparent effect on navigation, is prohibited in the absence of a permit even if Congress thought at the time of enactment that permits would not or could not be withheld on the ground that the material discharged was merely a pollutant." 482 F.2d at 447 . Alternatively, the First Circuit appears to have taken the view that Congress contemplated forbidding even the unauthorized discharge of pollutants at the time the Refuse Act was passed. See United States v. Kennebec Log Driving Co., 491 F.2d 562, 569 n.23 (1st Cir. 1973), cert. denied, 417 U.S. 910 (1974). This and other similar problems were mooted by passage of the FWPCA, which clearly prohibits unauthorized discharge of pollutants. See notes 73-79 infra and accompanying text.

73. FWPCA.

74. 33 U.S.C. $\$ 1311$ (a)(Supp. IV 1974): "Except as in compliance with this section and sections $1312,1316,1317,1328,1342$, and 1344 of this title, the discharge of any pollutant shall be unlawful." The permit program most germane to this discussion is the one pertaining to dredging and filling which is administered by the Corps of Engineers. See id. $\$ 1344 ; 33$ C.F.R. $\S$ $209.120(\mathrm{~g})(1976)$.

75. FWPCA $\$ 502(12), 33$ U.S.C. $\$ 1362(12)(S u p p$. IV 1974) provides:

The term "discharge of a pollutant" . . . means (A) any addition of any pollutant to navigable waters from any point source, (B) any addition of any pollutant to the 
waters" as "the waters of the United States, including the territorial sea." "76

The FWPCA is generally concerned with keeping the waters of the United States in a pristine state for the public and for commercial users. The Act attempts to accomplish this goal by regulating private activities that affect water quality. But Congress has stopped short of attenipting to assert plenary control over every activity which may potentially affect the chemical, physical or biological characteristics of the nation's waters. On its face, section 301(a) appears to be directed only against discharges and not against activities such as dredging, in which nuaterial is excavated or removed from the water. ${ }^{77}$ Moreover, in order for an activity to be subject to federal control under the FWPCA, the discharge must emanate from an identifiable "point source."78 This would seem to exclude such pollution-producing activities as agricultural run-off. Finally, there is also some question as to whether the FWPCA can be used to prevent the erection of structures, such as piers and wharves, in the absence of a showing that water quality is actually affected. ${ }^{79}$

By far, the most troublesome problem in defining the scope of the FWPCA has been the identification of the "waters of the United States"

waters of the contiguous zone or the ocean from any point source other than a vessel or other floating craft.

The term "pollutant" is defined in FWPCA $\S 502(6), 33$ U.S.C. $\$ 1362(6)$ (Supp. IV 1974):

The term "pollutant" means dredged spoil, solid water, incinerator residue, sewage, garbage, sewage sludge, munitions, chemical wastes, biological materials, radioactive materials, heat, wrecked or discarded equipment, rock, sand, cellar dirt and industrial, municipal and agricultural waste discharged into the water. . . .

For the definition of "point source," see note 78 infra.

76. FWPCA § 502(7), 33 U.S.C. § 1362(7)(Supp. IV 1974).

77. But see Weiszmann v. District Eng'r, 526 F.2d 1302, 1306 (5th Cir. 1976):

[T] he district court correctly found that discharge of "sediment" from the dredging amounted to a violation of the statutory prohibition against the discharge of a "pollutant." Section 502 of the Act defines "pollutant" to include "dredge spoil." 33 U.S.C.A. § 1362. Nor can we find merit to Weiszmann's semantical assertion that the evidence fails to show a statutory violation because it established merely a "spill" into waters, rather than a "discharge."

78. See FWPCA § 502(12)(A), 33 U.S.C. \$ 1362(12)(A) (Supp. IV 1974); also see the discussion in note 75 supra and accompanying text. The Act defines "point source" as follows:

The term "point source" means any discernible, confined and discrete conveyance, including but not limited to any pipe, ditch, channel, tunnel, conduit, well, discrete fissure, container, rolling stock, concentrated animal feeding operation, or vessel or other floating craft, from which pollutants are or may be discharged.

FWPCA § 502(14), 33 U.S.C. § 1362(14) (Supp. IV 1974).

79. The question arises, for example, whether the driving of a wooden pile into a water body's bed constitutes a "discharge of a pollutant" within the meaning of the FWPCA. (See the definition of "pollutant" quoted in note 75 supra). If the construction of a pier or other structure has no discernible effect on the chemical, physical or biological quality of the water, it is doubtful whether this is the type of activity which the FWPCA is really attempting to reach. On the other hand, applying the FWPCA to structures would serve a practical purpose for the government. While section 10 of the Rivers and Harbors Appropriation Act of 1899 prohibits the construction of structures in any water of the United States, whether navigable or nonnavigable, that Act unlike the FWPCA contains no civil penalty provisions. In certain situations, a civil penalty may be the most appropriate enforcement remedy for an unauthorized structure. See notes 115-19 infra and accompanying text. 
that are subject to protection from unauthorized discharges. ${ }^{80}$ Since the Act is expressly concerned with water quality and not navigation, traditional tests, such as the mean high water mark, would not appear to be useful. ${ }^{81}$ Within the last three or four years, several courts have struggled to define "waters of the United States," as the term is used in the FWPCA, ${ }^{82}$ but little case law with broad and practical applicability has enierged. The approach still seems to be ad hoc. Without a precise set of facts before it, the District Court for the District of Columbia could conclude only that "waters of the United States," as used in the FWPCA, "is not limited to the traditional tests of navigability" but rather includes the nation's waters to the maximum extent permissible under the commerce clause ${ }^{83}$ the court did not venture to suggest where the territorial limit night be. ${ }^{84}$ Where a particular discharge has been at issue, most courts have limited their opinions to whether FWPCA jurisdiction exists over the area in question and have not attempted to fashion a general jurisdictional test. ${ }^{85}$

In its new regulations implementing the FWPCA, the Corps of Engineers has taken an essentially territorial approach to jurisdiction. In substance, the regulations provide that FWPCA jurisdiction exists over all identifiable bodies of water landward to their mean or ordinary high water marks and also over all contiguous coastal and freshwater wetlands to the extent that they are "periodically inundated" and are characterized by certain types of vegetation normally associated with the periodic presence of saline, brackish or fresh water. ${ }^{86}$ Jurisdiction over noncontiguous wetlands is left to the discretion of the individual District Engineers. ${ }^{87}$ Initially, it would seem that the phrase "periodically inundated" might be too inipre-

80. See notes 75-76 supra and accompanying text for an explanation of how the term "waters of the United States" controls the application of the FWPCA.

81. This has been the view of the courts. See, e.g., Conservation Council v. Costanzo, 398 F. Supp. $653,673-74$ (E.D.N.C. 1975).

82. FWPCA $\S 502(7), 33$ U.S.C. $\$ 1362(7)$ (Supp. IV 1974).

83. Natural Resources Defense Council v. Callaway, 392 F. Supp. 685, 686 (D.D.C. 1975).

84. See id.

85. See United States v. Smith, 7 E.R.C. 193 (E.D. Va. 1975); Weiszmann v. District Eng'r 7 E.R.C. 1523 (S.D. Fla. 1975), rev'd and remanded on other grounds, 526 F.2d 1302 (5th Cir. 1976); Leslie Salt Co. v. Froehlke, 403 F. Supp. 1292 (N.D. Cal. 1974); United States v. Holland, 373 F. Supp. 665 (M.D. Fla. 1974); United States v. Ashland Oil and Transp. Co., 364 F. Supp. 349 (W.D. Ky. 1973), aff'd, 504 F.2d 1317 (6th Cir. 1974). In each case, the court was concerned almost exclusively with determining whether FWPCA jurisdiction existed over the precise area in controversy and not with fashioning a test for the limit of FWPCA jurisdiction. In Conservation Council v. Costanzo, 398 F. Supp. 653, 668, 674 (E.D.N.C. 1975), Chief Judge Larkins held that an area containing certain species of saline marsh vegetation and "flooded a few times a year as a result of certain infrequent acts of nature" fell within the jurisdiction of the FWPCA. This is the closest thing to a jurisdictional standard that has been proposed thus far.

86. See 33 C.F.R. $\S 209.120$ (d)(2) (1976).

87. Id. $\S 209.120(\mathrm{~d})(2)(\mathrm{i})(i)$. 
cise to be practical, since it could fairly be argued that even 100-year flood plains are subject to periodic inundation. The added requirement of the conjunctive vegetation test, however, should tend to keep federal action within manageable limits and also to simplify the problems of proof in enforcement litigation. ${ }^{88}$

\section{ADMINISTRATIVE ENFORCEMENT OF RESTRICTIONS CREATED BY THE 1899 ACT AND THE FWPCA}

As presently construed, the Rivers and Harbors Appropriation Act of 1899 and the Federal Water Pollution Control Act Amendments of 1972 taken together effectively create federal easements over most of the waters and wetlands in the United States. The Army Corps of Engineers' Wilmington, North Carolina, District recently conducted a survey to assess the changes in that District's regulatory responsibilities that have resulted from the expanded concept of FWPCA jurisdiction ${ }^{89}$ The survey results illustrate the magnitude of federal regulatory involvement with state and private land and water resource use. Under either the 1899 Act or FWPCA, nearly 10,000 square miles, or approximately one-fourth of the total area covered by the Wilmington District, will be subject to federal regulation. ${ }^{90}$ This regulated area includes some 7,000 miles of tidal shoreline, 24,500 miles of rivers, creeks and tributaries, 206,350 acres of coastal marshes, and thousands of square miles of open water sounds stretching between the Virginia and South Carolina state lines. ${ }^{91}$ Enforcing federal restrictions on water resource use in an area this large presents enormous practical difficulties.

Given present resources, it is simply impossible to initiate legal action in connection with every violation of federal water resource protection laws. Even if sufficient resources were available, it is questionable whether every violation should result in litigation. Some violations are simply unintentional, and the perpetrators are perfectly willing to undertake voluntary corrective action if given the opportunity. Moreover, many violations are committed by persons of limited means. Exposing every one of them to the expense of complex and protracted litigation raises serious ethical, social and political questions. There is also the danger that resorting to litigation in every case would create a political and legislative backlash that would imperil the entire federal regulatory program. ${ }^{92}$ Finally, and perhaps most importantly,

88. See notes 70 supra and 185 infra and accompanying texts for a discussion of the importance of having a relatively clear-cut and simple test for proving jurisdiction and for establishing a geographical limit for work to be ordered under a remedial injunction.

89. See U.S. ARmy Corps of Engineers, Wilmington District, Progress in Civil WORKS, 1971-1980 (1975).

90. Id. at 4-5.

91. These figures are based on raw data which are summarized $i d$.

92. See generally Environmental LaW InSTItute, Enforcement of Federal and State 
the federal court system is simply not equipped to handle several thousand enforcement actions every year. ${ }^{93}$

Selective prosecution is one answer, but it is not a very satisfactory one. While limiting prosecutions to major and flagrant violators may draw public attention to the regulatory program, this practice also tends to make minor violators feel secure. Moreover, as a practical matter, the effect of the few serious violations, such as large unauthorized projects, may have less serious consequences for national interests than the cumulative impact of minor violations. ${ }^{94}$ Selective enforcement may also place the government at a disadvantage when seeking equitable relief in the courts. A showing that the perpetrator's neighbors were allowed to proceed with similar but smaller projects is bound to influence judicial awards of relief. ${ }^{95}$

In order to protect the public's interest im navigability and water quality effectively, every violation of federal use control laws should be detected and exposed, and each violator should be called upon to rectify his wrong. More important, there should be a practical, extra-judicial method for resolving a majority of cases. Unfortunately, neither the Rivers and Harbors Appropriation Act of 1899 nor the FWPCA provides the Corps of Engineers

Water Pollution Controls: A Report to the National Commission on Water Quality 27-62 (1975)(discussing the practical enforcement difficulties encountered by the Environmental Protection Agency and state regulatory authorities in administering the FWPCA).

93. By way of example, the Attorney General's Annual Report for 1975 indicated that during that fiscal year, seventy-five civil actions were initiated throughout the entire country to enforce the provisions of sections 10 and 13 of the 1899 Act, 33 U.S.C. $\$ \$ 403,407$ (1970), and the dredging and filling provisions of the FWPCA, FWPCA § 404, 33 U.S.C. § 1344 (Supp. IV 1974). See [1975] ATT'Y GEN. ANN. REP. 131. The author's survey of the United States Attorney's files for the Eastern District of North Carolina indicates that only ten of these civil actions were initiated in the Eastern District. On the other hand, the survey also discloses that eighty-five suspected violations of those laws had been reported by the Corps of Engineers' Wilmington District to the United States Attorney for the Eastern District of North Carolina and were pending as of January 1, 1977. If every one of these suspected violations were to result in civil enforcement proceedings in federal court, the result in fiscal year 1977 would be a 750 percent increase in enforcement litigation from fiscal year 1975.

94. In the areas where the federal enforcement program is most effective, minor violations are likely to present more of a problem than larger, more flagrant violations. Persons contemplating projects which involve considerable expenditures of time and money will usually opt for the security of the administrative permit process rather than risk litigation and serious financial loss. Moreover, unauthorized work on a large, visible project will normally attract immediate federal attention. On the other hand, a small property owner building a pier with scrap lumber rarely thinks in terms of potential financial loss, and his work is likely to escape attention for some time. Also see notes $189-90$ infra and accompanying text.

95. As a matter of law, the government would not be estopped from maintaining an enforcement action, but it is questionable whether the government could obtain, for example, a mandatory injunction compelling removal of the work. See notes 191-95 and 200-01 infra and accompanying text. Cf. United States v. Stoeco Homes, Inc., 498 F.2d 597 (3d Cir. 1974)(government surrendered its navigational servitude because it was the policy of the Corps of Engineers not to require permits for the activity at issue at the time the work was actually performed). 
with a means for convenient administrative resolution of enforcement matters. ${ }^{96}$ Once a violation of the statutes administered by the Corps of Engineers is detected, current Department of the Army regulations provide for issuance of a cease-and-desist order. ${ }^{97}$ This directive simply advises the apparent violator that he is violating the law and requests him to stop performing the work until the matter is resolved. If there is non-compliance with this cease-and-desist order, normal practice is to refer the matter directly to the Department of Justice for appropriate criminal or civil proceedings in federal court..$^{98}$ In short, the burden of enforcement is shifted immediately from the administrator to the prosecutor, and it is the prosecutor who must evaluate the case from a distance and decide whether legal action is warranted. If many violations are detected and handled in this fashion, one of two things is likely to occur: either prosecution will be dechined in a majority of cases or the federal district court docket will become filled with criminal and civil enforcement actions. Neither is a particularly desirable result.

In the Eastern District of North Carolina, ${ }^{99}$ federal agencies have found that expanding the administrative process beyond what is required by law or regulation offers a partial alternative to judicial enforcement proceedings. Upon receipt of a reported violation from the field, the Corps of Engineers' Wilmington District reviews available information to determine whether one of the laws it administers has been violated. ${ }^{100}$ If a violation is apparent, the

96. Under FWPCA § 309(a)(3), 33 U.S.C. $\$ 1319$ (a)(3)(Supp. IV 1974), the Administrator of the Environmental Protection Agency may issue an "administrative order" directing a person violating section 301(a) of the Act to comply with the law; if the order is ignored, the Administrator may commence a civil action to enforce it. He may not, however, assess and collect civil penalties; this is within the exclusive province of the courts under FWPCA \& 309(d), 33 U.S.C. $\S 1319$ (d). In any event, under FWPCA $\S 404,33$ U.S.C. $\$ 1344$, the Corps of Engineers is charged with the responsibility for administering the FWPCA as it relates to dredging or filling activities. The Act does not provide for the issuance of administrative orders by the Corps of Engineers. This gap might be filled by future amendments to the Federal Water Pollution Control Act, but it is questionable whether this is really necessary. See notes 109-12 infra and accompanying text.

97. 33 C.F.R. $\$ 209.120(\mathrm{~g})(12)(\mathrm{i})(1976)$.

98. Id. $\S 209.120(\mathrm{~g})(12)(\mathrm{ii})(a)(l)$. Referral can often be a cumbersome procedure. The District Engineer sends a report to his Division Engineer who, in turn, refers the matter to the Office of the Chief of Engineers in Washington, D.C. The case is then forwarded to the Attorney General who eventually sends it back to the local United States Attorney for prosecution. In certain limited situations, the Corps of Engineers' regulations provide for referral of an enforcement action directly from the District Engineer to the local United States Attorney. Id. $\S \S 209.120(\mathrm{~g})(12)(\mathrm{i})$ and $(\mathrm{ii})(a)(2)$. The recent trend has been toward enlarging the District Engineer's direct referral authority.

99. North Carolina's Eastern Federal Judicial District is comprised of the state's easternmost forty-four counties, or somewhat less than half of its total area. All of North Carolina's coast and coastal plain lies within the Eastern District.

100. A standard violation reporting system has been developed within the Eastern District. Local federal and state agencies concerned with the protection of waterways and wetlands have 
Corps issues a cease-and-desist order and requests the person performing the work to provide a written report on the activities within ten days. ${ }^{101}$ Copies of all cease-and-desist orders are furnished to the federal and state agencies which participate in reviewing Department of the Army permit applications, ${ }^{102}$ and each agency is requested to make an on-site inspection of the work within thirty days and to report its findings and recommendations to the District Engineer. ${ }^{103}$ The local United States Attorney's office also receives a copy of each cease-and-desist order. ${ }^{104}$

The procedure outlined above has several important advantages over past practice. Traditionally, the Corps of Engineers has had to rely primarily on its own limited resources to investigate and evaluate violations. Today, many agencies, each having special expertise and perspectives, are involved in the earliest stages of the enforcement process. The additional information provided to the Corps of Engineers by these agencies significantly reduces the possibility of error in the admimstrative process. ${ }^{105}$ The immediate and obvious mobilization of federal enforcement resources also helps to create an atmosphere that is conducive to administrative resolution of violations.

After a cease-and-desist order has been issued and all requested reports

been provided with an "Investigation Report Form" (SAW Form 421, Nov. 26, 1974), which has been distributed to all of their personnel in the field. One side of the form has space for recording essential factual information about the suspected violation. The back of the form has been stamped with the Corps of Engineers' address in Wilmington, North Carolina, and is franked. When a field inspector from any one of the participating agencies detects a suspected violation, he fills out the form and folds, staples and mails it to the Wilmington District Office. This procedure has yielded two benefits. First, the Corps of Engineers' regulatory personnel are effectively augmented by dozens of field inspectors from other agencies, and second, the Corps normally receives initial notice of a violation within a few days of its occurrence.

101. 33 C.F.R. $\$ 209.120(\mathrm{~g})(12)(\mathrm{ii})$ (1976).

102. Corps of Engineers regulations require solicitation of the views of appropriate federal, state and local agencies on early construction permit application. Id. But no procedure has been established for meeting this requirement. See id. In the Wilmington, North Carolina District, cease-and-desist orders are normally sent to the U.S. Fish and Wildlife Service, the National Marine Fisheries Service, the Environmental Protection Agency, the North Carolina Division of Environmental Management, the North Carolina Division of Marine Fisheries and the Real Property Section of the North Carolina Department of Administration.

103. Upon completion of its field inspection, each agency is requested to complete a rather lengthy "Comments and Recommendations Report" which includes detailed physical and biological descriptions of the area surrounding the unauthorized work. This information not only affords a basis for requesting that remedial work be performed, but if judicial proceedings ultimately result, the reports provide the United States Attorney with detailed information about the facts of the case and the testimony of prospective witnesses.

104. When he receives a copy of a cease-and-desist order, the United States Attorney is immediately alerted that a violation is in progress and that a temporary restraining order may be required on short notice. The cease-and-desist order normally contains a brief description of the location and nature of the work and sufficient additional information to enable the United States Attorney to draw a complaint without a further exchange of correspondence.

105. Administrative oversights may affect the nature of relief available to the government in judicial proceedings. See notes 200-204 infra and accompanying text. 
have been received, the Corps of Engineers is then in a position to select an appropriate enforcement approach. In the event that the violator chooses to ignore the District Engineer's directive to stop the unauthorized work the prosecutor has already been alerted and normally has sufficient information about the facts to initiate judicial proceedings immediately. ${ }^{106}$ Experience indicates, however, that this is rarely necessary. When faced with an almost instantaneous federal response, most persons will stop and opt for an administrative solution if given the choice. ${ }^{107}$ Assuming that the work does stop, enough information about the violation will have been gathered at this point to enable the Corps of Engineers to determine what further administrative action may be appropriate.

At this stage of the enforcement proceeding, the Corps of Engineers' Wilmington District normally attempts to distinguish unauthorized work that is susceptible of restoration to the status quo ante from work that is not. Where it appears reasonable to require some remedial work to correct a violation, the Corps of Engineers' cease-and-desist order is customarily followed by an informal administrative order directing the responsible party to perform specified remedial work; the stated alternative to compliance is referral of the matter to the United States Attorney for appropriate criminal or civil proceedings. In other jurisdictions, this step is omitted and the matter is referred for judicial proceedings without giving the potential defendant any informal opportunity to correct his wrong. ${ }^{108}$

A violator is not obliged by law or regulation to obey the Corps of Engineers' administrative restoration order; the only impetus to obey is the threat of litigation. ${ }^{109}$ Interestingly enough, however, this practice did not

106. See note 104 supra and accompanying text. Cease-and-desist orders are normally sent to the violator by certified mail. As soon as the receipt is returned to the Corps of Engineers, the project is kept under surveillance to ensure that the work has, in fact, stopped. If the work continues, the United States Attorney is notified by telephone to seek a temporary restraining order. Once a complaint is filed and a temporary restraining order is sought, responsibility for the case passes from the Corps of Engineers to the Department of Justice. This shift in responsibility narrows the range of options available to the person performing the work for he no longer has the opportunity to resolve the conflict within the somewhat more flexible framework of the administrative process.

107. According to an informal survey by the author, 179 violations of the 1899 Act and FWPCA were reported to the United States Attorney by the Corps of Engineers' Wilmington District during 1976. Of this number, only one appears to have required the entry of a temporary restraining order. See also ENVIRONMENTAL LAW INSTITUTE, supra note 92, at 27: "Successful regulation depend[s] upon the consent of the regulated, who [have] the power to frustrate officially-declared objectives if they [choose] to do so." The mood of the regulated often depends on how effectively the government wields both the carrot and the stick.

108. See 33 C.F.R. $\$ 209.120(\mathrm{~g})(12)(\mathrm{i})(1976)$.

109. Several considerations support an administrative approach to restoration. To begin with, the procedure is not without precedent. The FWPCA expressly provides for the issuance of administrative orders by the Environmental Protection Agency. See note 96 supra. Similar$l y$, there is no real conceptual difference between an administrative restoration order and a written demand for a debt due or a demand for tender of performance under a contract; both are 
begin as an intentional effort to compel corrective work extrajudicially. It was prompted by difficulties encountered in seeking equitable relief in the courts. The primary judicial instrument for compelling a party who has violated the 1899 Act or FWPCA to rectify his wrong is the mandatory injunction. ${ }^{110}$ An equitable remedy, the mandatory injunction compelling restoration or removal of unauthorized work is not routinely available to the government and will normally not be issued where the equities favor a defendant. ${ }^{111}$ Prior to the advent of administrative restoration orders, many defendants would raise the allegation that they would have been willing to correct their unauthorized work voluntarily had they been given the opportunity, as a defense to or in mitigation of the government's claim for relief. Perhaps such pleas were meritorious, for restoration or corrective work is now being performed voluntarily in a majority of cases. ${ }^{112}$

In any event, if a person performing unauthorized work complies voluntarily with the Corps of Engineers' administrative restoration order, the United States Attorney is so advised, and the matter normally ends there. ${ }^{113}$ If the violator refuses to comply, the Corps of Engineers refers the matter for legal proceedings. As a practical matter, every case involving a refusal to perform corrective work must be referred for litigation or the

prerequisites for obtaining judicial relief in appropriate contexts. And as a matter of fundamental fairness, it seems that a violator should be apprised of what the government expects of him before he is actually served with a civil or criminal complaint.

Consider also the practical effect of a successful challenge to an administrative restoration order in the courts. If the order is set aside, the Corps of Engineers is obliged by regulation to cease all further efforts toward administrative resolution and to refer the matter to the Department of Justice for legal action. See 33 C.F.R. $\$ 209.120(\mathrm{~g})(12)(i)(1976)$. The violator will have gained nothing but a second law suit and will have effectively deprived himself of the option to resolve the conflict informally. Moreover, the validity of an administrative order would have no effect on the government's right to initiate subsequent civil proceedings. See United States v. New York Cent. R.R., 252 F. Supp. 508, 512-13 (D. Mass. 1965), aff'd per curiam, 358 F.2d 747 (1st Cir. 1966).

110. See notes $188-90$ infra and accompanying text.

111. See notes 191-95 infra and accompanying text.

112. According to the informal survey taken by the author, of the 179 violations reported within the Eastern District in 1976, ten (5.6\%) resulted in civil legal proceedings, eighty-four (47\%) were resolved voluntarily in the administrative process, three (1.7\%) are awaiting initiation of legal proceedings, and eighty-two (45.7\%) are awaiting administrative resolution. Based on cases actually resolved during that year, the District Corps of Engineers is achieving a voluntary compliance rate of $89 \%$.

113. Upon receipt of notification from the Corps of Engineers that corrective work, if any, has been satisfactorily completed, the United States Attorney normally advises the Corps of Engineers by letter, with a copy to the person performing the work, that legal action will not be initiated and that the United States Attorney's file is being closed. In theory, a legal action could be initiated regardless of whether voluntary corrective work had been performed, but it is questionable whether a court of equity would be willing to give the government any remedy at all unless there were some additional federal regulatory interests to be vindicated. Such a practice might also discourage people from participating in the administrative process and would amount to a waste of the Justice Department's limited resources. 
whole concept of extrajudicial enforcement breaks down. While some unauthorized work is undoubtedly the result of simple ignorance or inadvertence, there are also many cases where the work was knowingly undertaken as a financial risk. Where a project may result in significant economic gain but clearly would not have been permitted by federal authorities if application had been made in advance, only the certainty of enforcement litigation will induce voluntary compliance with an administrative restoration order. ${ }^{114}$

Notwithstanding the current dearth of formal administrative procedures for enforcing federal restrictions on the use of waterways and wetlands, experience in the Wilmington District indicates that at least one practical method of prompting voluntary compliance is available to the agencies. No such method exists, however, where correction of the violation is impractical or unnecessary. For example, the Corps of Engineers occasionally finds that it would have granted a permit for unauthorized work if the person performing it had applied in advance. A court of equity would be understandably reluctant to require dismantling of a structure or removal of a fill if the defendant could subsequently obtain permission to perform identical work. ${ }^{115}$ In short, there is no clearly legitimate basis for an administrative restoration order in such cases. ${ }^{116}$ On the other hand, simply allowing the work to remain in place without subjecting the owner to any penalty disadvantages others who take the time and trouble to apply for permits in advance. One solution is to impose a fine or civil penalty upon parties who fail to obtain permits for their work, but this is currently possible only by court order. ${ }^{117}$

The result is an anomalous situation. Minor and less serious violations are more apt to result in litigation than serious violations which require extensive corrective work simply because administrative agencies lack the

114. For example, the Corps of Engineers will rarely, if ever, issue a permit for large-scale filling in coastal wetlands. On the other hand, there is tremendous demand for water-front property and the supply is limited and decreasing steadily. Financial gain from such a project can therefore be considerable. If a developer believes that there is a good chance that he can ultimately avoid a mandatory injunction compelling him to remove the fill, he will be unlikely to pay much attention to an administrative restoration order.

115. See United States v. Joseph G. Moretti, Inc., 478 F.2d 418 (5th Cir. 1973).

116. In the absence of a reasonable expectation that an administrative restoration order will be enforced by a judicial decree, there is simply no inducement for the person performing the work to obey it. Thus, in order to make this enforcement instrument effective, it is incumbent on the Corps of Engineers to remain continuously aware of all developments in the law of remedies. Conversely, the courts can be of great assistance to administrative agencies and, at the same time, reduce their enforcement workloads by developing uniform and predictable rules for the application of mandatory injunctive relief. See notes 209-11 infra and accompanying text.

117. The civil penalties authorized by FWPCA $\$ 309$ (d), 33 U.S.C. $\$ 1319$ (d)(Supp. IV 1974), may only be imposed judicially. See FWPCA § 309(b), 33 U.S.C. \& 1319(b). The Rivers and Harbors Appropriation Act of 1899 contains no provision authorizing civil penalties. 
means to deal effectively with the former. Legislation is required to correct this anomaly: by giving the Corps of Engineers and the Environmental Protection Agency the authority to impose and collect civil penalties for certain classes of minor violations, a great deal of largely unnecessary litigation could be eliminated. ${ }^{118}$ At a minimum, provision should be made to allow minor cases to be heard by United States Magistrates rather than burdening the United States District Courts. ${ }^{119}$

No matter how sophisticated the administrative enforcement process may become, there will always be some violations which can only be resolved judicially. An example of such a situation is presented by the recent case of United States v. Golden Acres, Inc. ${ }^{120}$ In that case, a developer filled some wetland areas adjacent to the Atlantic Intracoastal Waterway. Before any enforcement action was taken, portions of the filled areas were subdivided into lots and sold to purchasers who had no knowledge that the filling had been unauthorized. The violation was serious, but the court was sensitive about requiring the defendant to perform remedial work on land belonging to innocent purchasers who were not parties to the litigation. ${ }^{121}$ The solution was to require restoration of the areas still owned by the defendant and to impose a civil penalty in connection with the fill that had

118. For example, under 46 U.S.C: $\$ 1484$ (Supp. IV 1974), the United States Coast Guard is empowered to assess and collect civil penalties for violations of the Federal Boat Safety Act of 1971 , id. $\$ \$ 1451$ et seq. If administrative efforts to collect the penalty fail, judicial enforcement proceedings are limited to a relatively simple action on a debt of record. Id. $\$ 1484$ (d) provides that proceedings to collect fines not in excess of $\$ 200$ may be brought before United States Magistrates. See also 33 C.F.R. \$ 1.07 (1976)(administrative regulations implementing the civil penalty provisions of the Federal Boat Safety Act).

There has been growing support in recent years for administrative imposition of civil money penalties. See Goldschmid, Report in Support of Recommendation 72-6: An Evaluation of the Present and Potential Use of Civil Money Penalties as a Sanction by Federal Administrative Agencies, in 2 ADMINISTRATIVE CONFERENCE OF THE UNITED STATES RECOMMENDATIONS AND REPORTS 896 (1972); Recommendation 72-6: Civil Money Penalties as a Sanction, in ADMINISTRATIVE CONFERENCE OF THE UNITED STATES, supra, at 67. For a discussion of some of the impediments to such programs, see Comment, The Constitutional Rights to Trial by Jury and Administrative Imposition of Money Penalties, 1976 Duke L.J. 723.

119. Under 18 U.S.C. $\$ 3401$ (1970), a United States Magistrate has jurisdiction to hear only criminal cases involving "minor offenses." A minor offense is statutorily defined as "misdemeanors punishable under the laws of the United States, the penalty for which does not exceed imprisonment for a period of one year, or a fine of not more than $\$ 1,000$, or both . . . " Id. $\S$ 3401(f). Because of their potential severity, the criminal fine provisions of the FWPCA and those that accompany sections 10 and 13 of the 1899 Act, see notes 125-28, 131 infra and accompanying text, place both of these statutes outside the jurisdiction of the United States Magistrates. See generally Doub \& Kestenbaum, Federal Magistrates for the Trial of Petty Offenses: Need and Constitutionality, 107 U. PA. L. REv. 443 (1959). A magistrate has no jurisdiction to try or decide a civil enforcement action. See 28 U.S.C. \$ 636 (Supp. IV 1974).

120. No. 76-0023-CIV-4 (E.D.N.C. Jan. 13, 1977).

121. See id., slip op. at 6-7. The precise ground for declining to compel restoration of the area which had been subdivided and sold was that the purchasers had not been made parties to the action. The court offered no opinion as to what the result might have been if the purchasers had been joined as parties defendant. Id. at 7 . 
already been sold. Such a case requires adjudication and is not really amenable to administrative resolution. ${ }^{122} \mathrm{~A}$ similar problem exists where a violation is serious but restoration would do more harm than good. ${ }^{123}$ In such a situation, the solution may be to impose a large civil penalty or to restrict the defendant's future use of the unauthorized work. ${ }^{124}$ Cases such as these require a careful weighing of the equities and competing policy considerations, a function best performed by a neutral body and not by one of the adversaries.

\section{JUdICIAL ENFORCEMENT OF RESTRICTIONS CREATED BY THE 1899 ACT AND THE FWPCA}

When representing the United States in judicial proceedings to enforce the restrictions created by the Rivers and Harbors Appropriation Act of 1899 and the FWPCA, a Umited States Attorney stands in a somewhat different position from counsel for a private litigant attempting to enforce easement rights. The outcome of each enforcement action affects the public's view of the federal regulatory program as a whole. Defendants are also members of the public and have a right to expect that the law will be administered fairly and uniformly, and the prosecutor must therefore niake every attempt to be consistent in his approach to similar violations. On the other hand, every case has its peculiarities, and it is not always easy to categorize cases or to develop completely uniform approaches. What is important is that the prosecutor have a rational basis for his various approaches to different types of violations and that he be prepared to explain to the public, as well as to the courts, his reasons for proceeding differently in apparently similar cases.

122. Where restoration would affect persons who are probably not liable for a violation, an administrative restoration order will rarely be appropriate. $C f$. United States v. Stoeco Homes, Inc., 498 F.2d 597 (3d Cir. 1974). Even if the Corps of Engineers possessed this authority to assess and collect civil penalties, see notes $117-18$ supra and accompanying text, the question arises whether this is really a situation where a civil penalty should be administratively imposed. The district court in Golden Acres heard a great deal of evidence and carefully calculated a civil penalty which would effectively deprive the defendant of any monetary gain he had realized as a result of the unauthorized work. See United States v. Golden Acres, No. 76-0023-CIV-4, slip op. at 7-8 (E.D.N.C. Jan. 13, 1977). Such determinations have traditionally been a part of the judicial, and not the administrative, process.

123. For example, refilling an illegally excavated canal might cause more harm to fish and wildlife than allowing it to remain.

124. If one objective of enforcement is to ensure that a defendant does not profit from his unauthorized work, a prohibitory injunction restricting future use of the illegal fill area or structure might serve this purpose. Any argument that such restrictions amount to an unconstitutional taking in violation of the fifth amendment would seem to be negated by the existence of the government's paramount navigational easement and by the fact that the property was created illegally. Cf. United States v. Stoeco Homes, Inc., 498 F.2d 597, 607-08 (3d Cir. 1974). On the other hand, if the work has already disrupted the environment or adversely affected other national interests, but is being allowed to remain in place for some reason of policy, it is questionable whether it would be in society's best interest to allow the property to remain completely unproductive in perpetuity. 
While a United States Attorney may often face a complicated task in initiating legal proceedings to enforce the 1899 Act and the FWPCA, his burden is alleviated somewhat by the availability of several forms of relief which are unavailable to a private litigant. Perhaps the most significant advantage possessed by the government is that it has the option of using the criminal process to enforce its rights. In addition, within the general framework of civil proceedings, the United States has at its disposal not only the traditional actions for damages or for an injunction but also the right to request that a monetary penalty be assessed against the defendant. In certain situations, the government also has the power to employ its own resources to abate unauthorized activities extrajudicially and later to proceed civilly to recover the costs of its self-help efforts.

\section{A. Criminal Penalties}

Both the Rivers and Harbors Appropriation Act of 1899 and the Federal Water Pollution Control Act of 1972 contain criminal provisions. Section 12 of the 1899 Act makes it a misdemeanor to violate any of the provisions of section 10 and requires a fine of $\$ 500$ to $\$ 2500$ or up to one year imprisonment (in the case of a natural person) or both. ${ }^{125}$ Similarly, section 16 of the 1899 Act $^{126}$ makes it a misdemeanor to violate any of the provisions of section $13,{ }^{127}$ commonly known as the Refuse Act; the punishment is the same as for violations of section 10 , except that a minimuni period of incarceration of thirty days is prescribed for natural persons. ${ }^{128}$ No proof of scienter appears to be required for conviction under the 1899 Act. ${ }^{129}$

The 1972 Amendments to the Federal Water Pollution Control Act also provide for criminal penalties, but proof that a violation was willful or negligent is required for conviction. ${ }^{130}$ On the other hand, the penalties are somewhat more harsh. Conviction under the FWPCA exposes the defendant to punishment "by a fine of not less than $\$ 2,500$ nor more than $\$ 25,000$ per day of violation or by imprisonment for not more than one year, or both."131

125. 1899 Act $\$ 12,33$ U.S.C. $\$ 406$ (1970).

126. Id. § 16, 33 U.S.C. $\$ 411(1970)$.

127. Id. $\S 13,33$ U.S.C. $\S 407$ (1970).

128. Id. $\S 16,33$ U.S.C. $\S 411$ (1970). The minimum period of imprisonment detracts from the usefulness of section 16 as an instrument for dealing with relatively minor violations.

129. See, e.g., United States v. White Fuel Corp., 498 F.2d 619, 622 (1st Cir. 1974): "In the seventy-five years since enactment, no court to our knowledge has held that there must be proof of scienter; to the contrary, the Refuse Act has commonly been termed a strict liability statute." In United States v. Standard Oil Co., 384 U.S. 224, 230 (1966), the Supreme Court expressly declined to rule on the point since the issues on appeal were restricted. There does not appear to be anything definitive in the case law concerning a scienter requirement for a violation of section 10, cf. United States v. Raven, 500 F.2d 728, 731 (5th Cir. 1974), cert. denied, 419 U.S. 1124 (1975), but it is generally felt that the same approach would be taken as in the Refuse Act.

130. See FWPCA § 309(c), 33 U.S.C. § 1319(c)(Supp. IV 1974).

131. Id. 
In some districts, the courts have added a new dimension to criminal proceedings by requiring the defendant to perform corrective work as a condition of probation. ${ }^{132}$

Criminal prosecution has several advantages from the enforcement perspective. First, since the stigma which results from a criminal conviction is far greater than that which attaches to an unsuccessful defendant in a civil action, it can be argued that proceeding criminally creates a greater deterrent. ${ }^{133}$ An even greater advantage is the speed with which the criminal enforcement process can be completed. Criminal cases have fewer timeconsuming steps than civil cases. ${ }^{134}$ Also, because of their statutory priority, criminal cases are normally set for trial well in advance of contemporaneously filed civil cases. ${ }^{135}$ Finally, the practice of making corrective work a condition of probation would appear to give criminal cases much of the remedial flexibility normally present in civil enforcement proceedings. ${ }^{136}$

Notwithstanding the advantages of proceeding criminally, the practice within the Eastern District of North Carolina has been to avoid use of the criminal process to enforce the provisions of the 1899 Act and the FWPCA. ${ }^{137}$ There are a number of reasons for this practice. Criminal prosecutions under these two statutes cannot be tried by United States Magistrates and must be placed on the district court's calendar. ${ }^{138}$ Adding significant numbers of enforcement cases to the criminal docket in a small judicial district can create a tremendous burden on the entire court system. ${ }^{139}$ In addition to the burden it imposes on the courts, the criminal

132. See Kramon, supra note 5 , at 259-60 n.130.

133. But see note 188 infra and accompanying text, discussing the formidable burden which a civil restoration order may place on a violator.

134. For example, Civil Rule 7(E) of the Local Rules of the United States District Court for the Eastern District of North Carolina provides for a 120-day discovery period commencing at the time that the answer or other responsive pleading is filed. This period can be extended on a showing of good cause. Discovery may be followed by pre-trial conferences and hearings pursuant to Rule 16 of the Federal Rules of Civil Procedure. Criminal actions, on the otler hand, must follow a much more rapid timetable. See, e.g., The Speedy Trial Act of 1974, 18 U.S.C. $\$ \$ 3161-3174$ (Supp. IV 1974).

135. Rule 50(a) of the Federal Rules of Criminal Procedure provides that "[p]reference shall be given to criminal proceedings as far as practicable." FED. R. CRIM. P. 50(a).

136. See Kramon, supra note 5, at $259-60$ n.130. But see notes 191-95 infra and accompanying text for the proposition that the defendant may have a right to an evidentiary hearing on the propriety of restoration. There may be a question as to whether the criminal process affords a defendant an adequate opportunity to be heard on this issue.

137. An examination of the District's files discloses that no criminal enforcement proceedings have been initiated in the Eastern District within at least the last three years. This is not to say, of course, that criminal proceedings might not be entirely appropriate in the case of a particularly flagrant violation.

138. See note 119 supra and accompanying text.

139. A civil enforcement action normally requires the services only of an Assistant United States Attorney and a United States District Judge; the Clerk of the Court and the United States Marshal Service may also be affected to a small degree. A criminal enforcement action, on the 
process has other disadvantages for the government as well. While many civil enforcement proceedings are heard by a court of equity, ${ }^{140}$ a criminal defendant under the 1899 Act or FWPCA is entitled to trial by jury. ${ }^{141}$ Moreover, the perspective of jury members is normally limited to the case before them, while the courts are more likely to have a broader view. By considering the federal regulatory system as a whole, judges are more apt to produce consistent enforcement results. Other difficulties of employing the criminal process include the loss of the advantages of the liberal civil rules of discovery and the much more stringent burden of proof which is imposed on the government in criminal cases.

Apart from the specific problems encountered in criminal proceedings, there is also the larger question of whether the criminal courts are suitable forums for resolving conflicts over land and water resource use. An enforcement action under the 1899 Act or the FWPCA often involves a variety of technical issues, policy considerations and equitable factors. While criminal prosecution may be entirely appropriate in an egregious case, it would appear that most enforcement matters require the kind of thoughtful and searching inquiry that can only be obtained in the more relaxed and flexible framework of a civil proceeding. ${ }^{142}$

\section{B. Injunctive Relief}

Section 12 of the Rivers and Harbors Appropriation Act of 1899 expressly provides that the removal of any structure erected in violation of section 10 of the 1899 Act $^{143}$ may be enforced by injunction. ${ }^{144}$ In United

other hand, requires that the already burdened United States Probation Office assume a role in the proceedings and that the Clerk of the Court and the Marshal Service accelerate and intensify their efforts in order to keep pace with requirements for timely arrest, arraignment, bond hearings, etc. See The Speedy Trial Act of 1974, 18 U.S.C. \$\$ 3161-3174 (Supp. IV 1974).

140. The seventh amendment only guarantees a right to trial by jury in "suits at common law." Where, as is often the case, civil enforcement proceedings under the 1899 Act and the FWPCA involve only a demand for injunctive relief, it seems clear that no right to trial by jury is available. See United States v. Louisiana, 339 U.S. 699, 706 (1950). The one situation in which it is established that trial by jury is available to a defendant is where the government uses its own resources to restore or remove unauthorized work and then initiates a civil action to recover the cost. See notes 151-55 infra and accompanying text. Such an action is simply an action for debt, see United States v. Perma Paving Co., 332 F.2d 754, 758 (2d Cir. 1964), a traditional common law action in which a jury is normally required. 5 MOORE'S FEDERAL PRACTICE ๆ 38.19[1] (2d ed. 1951). See generally H. Goldschmid, supra note 118; Comment, supra note 118.

141. See U.S. CONST. amend. VI. The maximum penalties provided by the FWPCA and Act of 1899, see text accompanying notes 125-31 supra, are too severe to circumvent the right to jury trial by classifying the violations as petty. See, e.g., Baldwin v. New York, 399 U.S. 66, 68-69 (1970).

142. See notes $191-95$ infra and accompanying text.

143. 1899 Act $\S 10,33$ U.S.C. $\S 403$ (1970).

144. Section 12 provides: 
States v. Republic Steel Corp. ${ }^{145}$ the Supreme Court held that injunctive relief is also available to enforce any other provision of the 1899 Act. According to the Court, such flexibility is necessary to ensure that the purposes of the Act are fully accomplished. Subsequent case law has shown that the types of injunctions available to enforce the provisions of the 1899 Act are as varied as the principles of equity and the minds of lawyers can conceive. ${ }^{146} \mathrm{~A}$ similar range of injunctive remedies appears to be available to enforce section 301(a) of the FWPCA. ${ }^{147}$

The prohibitory and mandatory injunction each have an important role in the enforcement of federal water resource legislation. The most obvious use of the prohibitory injunction is to restrain a defendant from violating an administrative directive to stop unauthorized work until judicial proceedings can be completed. ${ }^{148}$ More subtle is the function that prohibitory injunctive relief can serve in a permanent decree. At first, it may seem superfluous to restrain a defendant from performing further unauthorized work as part of a final order, since he is merely being told not to violate the law again-an obligation which is already imposed on him by statute. But in cases where a real threat of further unauthorized work exists, a permanent prohibitory injunction can serve a practical purpose: when its entry is accompanied by retention of jurisdiction by the court, future violations can be handled by a

[T] he removal of any structures or parts of structures erected in violation of the provisions of [section 10] may be enforced by the injunction of any district court exercising jurisdiction in any district in which such structures may exist, and proper proceedings to this end may be instituted under the direction of the Attorney General of the United States.

1899 Act $\S 12,33$ U.S.C. $\$ 406(1970)$.

145. 362 U.S. $482,491-92(1960)$. The case reversed a Seventh Circuit holding that section 12 's explicit authorization of injunctive relief only to abate unauthorized structures, see note 144 supra, effectively precluded the use of injunctions for any other purpose under the 1899 Act. See United States v. Republic Steel Corp., 264 F.2d 289, 304 (7th Cir. 1959).

146. For examples, see notes $148-50,188-90$ infra and accompanying text.

147. See FWPCA § 301(a), 33 U.S.C. § 1319(b)(Supp. IV 1974). United States v. Smith, 7 E.R.C. 1937 (E.D. Va. 1975), and United States v. Holland, 373 F. Supp. 665 (M.D. Fla. 1974), provide examples of cases where injunctions have actually been entered under the FWPCA.

148. Such use is contemplated in the All Writs section of the Judicial Code, 28 U.S.C. $\$ 1651$ (1970), and in Rule 65 of the Federal Rules of Civil Procedure. In determining whether to enter a preliminary injunction, most courts follow some variation of the four-part test originally set forth in Virginia Petroleum Jobbers Ass'n v. FPC, 259 F.2d 921 (D.C. Cir. 1958), and consider: (1) whether the plaintiff is likely to prevail on the merits; (2) whether the plaintiff is likely to suffer irreparable injury in the absence of a preliminary injunction; (3) the extent to which the injunction may cause harm to other parties interested in the proceeding; and (4) where the public interest lies. In enforcement proceedings under the 1899 Act and the FWPCA, these factors will normally favor the government. Moreover, at least one court has held that the government need not make a showing of irreparable harm in order to obtain an injunction to enforce the provisions of the 1899 Act. See United States v. Sexton Cove Estates, Inc., 389 F. Supp. 602, 609 (S.D. Fla. 1975), rev'd and remanded on other grounds, 526 F.2d 1293 (5th Cir. 1976). But see United States v. Stoeco Homes, Inc., 498 F.2d 597, 611 (3d Cir. 1974); United States v. Kentland-Elkhorn Coal Corp., 353 F. Supp. 451, 455 (E.D. Ky.1973). 
relatively simple contempt proceeding rather than by initiation of an entirely new lawsuit. ${ }^{149}$

Perhaps the single most effective instrument for enforcing federal control over private activities in waters and wetlands is the mandatory injunction. ${ }^{150}$ In most cases, the purposes of the 1899 Act and the FWPCA are best achieved by compelling the defendant to undo what he has unlawfully done by restoring the affected waters and wetlands, as nearly as possible, to their status quo ante. The public can thereby regain use of the affected water for navigation and enjoy the benefits of having the waters and wetlands in their pristine state. The cost and effort associated with restoration also create an effective deterrent to others contemplating similarly unauthorized work. It should be emphasized, however, that despite its unique appropriateness, the mandatory injunction is an equitable remedy which is only available at the discretion of the court. In order to develop a scheme for determining when mandatory injunctive relief is appropriate, it is first necessary to examine the other civil remedies which are available to the government in enforcing water resource legislation.

\section{Self-Help and Damages}

While no specific statute explicitly authorizes federal agencies to use their own resources to remove unauthorized work, that prerogative has been implied in certain situations. In United States v. New York Central Railroad, ${ }^{151}$ for example, the Corps of Engineers was permitted to act on its own to remove a collapsed bridge which was limiting a river's navigable capacity. ${ }^{152}$ The dimensions of self-help were further explored in United States v. Perma Paving Co., ${ }^{153}$ where the United States was allowed to recover the cost of dredging a shoal from a riparian owner after his misuse of his property had obstructed a navigable river. ${ }^{154}$ In so ruling, Judge Friendly made a strong case for self-help in the protection of water resources:

The remedy of damages is less burdensome to the defendant since it relieves him of having to undertake a task which he may have neither the knowledge nor the skill to perform or supervise. More important, it

149. Upon government submission of affidavits documenting that the defendant is continuing the work from which he was enjoined, the proceeding would probably take the form of a hearing to show cause why the defendant should not be held in contempt.

150. See, e.g., United States v. Golden Acres, Inc., No. 76-0023-CIV-4, slip op. at 6 (E.D.N.C. Jan. 13, 1977).

151. 252 F. Supp. 508 (D. Mass. 1965), aff'd per curiam, 358 F.2d 747 (1st Cir. 1966).

152. The Railroad Company's negligence was shown to have caused the collapse, which in turn caused the obstruction. See 252 F. Supp. at 512-13.

153. 332 F.2d 754 (2d Cir. 1964).

154. The property, which was owned by the City of New York and leased to a contractor who was authorized to place fill materials upon it, was low and swampy, and the fill had the effect of forcing the underlying mud out into the river. See id. at 756. 
assures the United States the speedy and competent removal of an obstruction to navigation which may be vital to the avoidance of accidents imperiling life, limb or property, to the interests of commerce, or even to the national defense. We can think of no sensible reason why Congress should have desired that if the executive branch chooses to effect immediate removal of an obstruction, through the services of the Corps of Engineers or otherwise, rather than resort to the slower injunctive process of the courts, the offender should thereby escape his due. ${ }^{155}$

Notwithstanding the broad warrant for self-help in the Perma Paving case, the Corps of Engineers has generally been reluctant to use its own resources to remove unauthorized work. In part, this may be the result of a lack of confidence that self-help remedies will always be upheld by the courts. ${ }^{156}$

A cautious approach to self-help can eliminate much of the uncertainty surrounding its use. A good example is provided by the recent decision in United States $v$. Peele, ${ }^{157}$ where the government initiated a civil action to compel removal of a fishing pier, the construction of which had originally been permitted by the Corps of Engineers. After the pier was built, the owner failed to maintain proper navigational lights, and his permit was revoked. As an alternative to a mandatory injunction compelling removal of the pier, the government sought a declaratory judgment that it had the authority to remove the structure and that the owner would be liable for the cost of removal. ${ }^{158}$ The district court ordered the defendant to remove the pier within sixty days; at the expiration of that period, the government was authorized to remove the structure and bill the owner for the cost. ${ }^{159}$ The declaratory judgment provides a sure way for the government to establish the propriety of self-help in a given case before it performs the work.

To date, self-help has been specifically upheld only where the unauthorized work constituted an actual obstruction to navigation. ${ }^{160}$ Neverthe-

155. Id. at 758 .

156. It would be very rare for an agency such as the Corps of Engineers to have funds appropriated for the specific purpose of removing unauthorized activities. If, for some reason, the agency were unable to recover the cost of removal or restoration, the officer having fiscal responsibility would undoubtedly be very concerned that he might be questioned about misappropriation of funds.

157. No. 75-0001-CIV-2 (E.D.N.C. Apr. 19, 1976).

158. The fishing pier in question was not attached to the shore but stood out in the water approximately two and one-half miles from the nearest land. The alternative prayer was prompted by evidence that defendant lacked both the means and expertise to remove the pier himself. See id, slip op. at 8. See also United States v. Perma Paving Co., 332 F.2d 754, 758 (2d Cir. 1964)(lack of expertise considered).

159. No. 75-0001-CIV-2, slip op. at 9.

160. In United States v. New York Cent. R.R., 252 F. Supp. 508 (D. Mass. 1965), there was a specific finding by the court that the collapsed bridge constituted an "unreasonable obstruction to navigation."'Id. at 510,512 . Such a finding was also essential to the decision in United States v. Perma Paving Co., 332 F.2d 754, 758 (2d Cir. 1964). In United States v. Peele, the 
less, the underlying rationale appears to support the use of this remedial device in any case where unauthorized work has a discernible effect on either navigability or water quality. United States $v$. Underwood ${ }^{161}$ lends some support to this proposition. In that case, the government initiated a civil action alleging that the defendant had violated section 10 of the 1899 Act by dredging the Weeki Wachee River without a Department of the Army permit. As relief, the government sought an order compelling restoration of the riverbed and shoreline to their original condition or, alternatively, damages equal to the cost of such restoration. In granting the government's motion for summary judgment on the issue of liability, the court noted the right to self-help by way of dictum: "Where the party causing the injury to navigable waters refuses to remedy the situation or for some other reason the United States is compelled to perform the remedy, the government is entitled to the equivalent cost in damages." 162

It should be emphasized, however, that although the courts will imply civil liability to reimburse the government for the costs of restoration, damages cannot be awarded unless the government has actually performed the restoration work. Otherwise, a monetary award would be in the nature of a civil penalty, for which the 1899 Act makes no provision. ${ }^{163}$ Even if a simple, pre-restoration damage remedy could lawfully be implied, it may be questioned whether the cost of restoration would be the proper measure. Damages are normally compensatory in nature. ${ }^{164}$ Prior to performing corrective work, the only harm for which the government could seek compensation would be the diminution in value of the water resources affected by the unauthorized work, and this loss need bear no particular relationship to the cost of restoration.

\section{Civil Penalties}

Unlike the Rivers and Harbors Appropriation Act of 1899, which does not include any provision for civil penalties, the FWPCA explicitly provides for judicial imposition of civil penalties of up to $\$ 10,000$ per day of violation in addition to, or in lieu of, other relief. ${ }^{165}$ The civil penalty provisions of the FWPCA significantly increase a court's ability to fashion a judgment to fit the particular circumstances of a given case. The preferred mandatory injunction remedy is not always equitable or feasible. For example, in United States $v$. Arnett, ${ }^{166}$ the government brought an action under

unlighted pier in question was outside the normal navigation channels but in an area frequented by small fishing craft. No. 75-0001-CIV-2, slip op. at 4-5 (E.D.N.C. Apr. 19, 1976).

161. 344 F. Supp. 486 (M.D. Fla. 1972).

162. Id. at 494.

163. See United States v. New York Cent. R.R., 252 F. Supp. 508, 512 (D. Mass. 1965).

164. See generally D. DOBBS, HANDBOOK ON THE LAW OF REMEpIES $\$ 3.1$ (1973).

165. FWPCA \& 309(d), 33 U.S.C: § 1319(d)(Supp. IV 1974).

166. No. $75-0008-C I V-7$ (E.D.N.C. Apr. 14, 1976). 
both the 1899 Act and the FWPCA to compel the defendant to remove an unauthorized bulkhead and fill project. ${ }^{167}$ The defendant had taken steps to secure a Department of the Army permit for most of the work but had failed to have it validated; in addition, the contractor performing the work had misread the permit specifications and had placed the bulkhead out in the water some twelve feet beyond where the Corps of Engineers had directed that it be placed. To make matters worse, the contractor died after completing the work, leaving the defendant with no recourse against him. In imposing a fairly substantial civil penalty upon the defendant, the district court commented on the inappropriateness of injunctive relief in this unusual situation:

The Government's arguments for mandatory injunction in this case are both substantial and persuasive. Mandatory. injunction, however, is an equitable remedy and the propriety of granting such relief depends on the facts and circumstances of the particular case. Here, there clearly was no intent on the part of the defendant to violate or even evade the law. The violations occurred as a result of a combination of inadvertence, errors in judgment, several mistakes, and an element of pure chance. .. . Considering all of the facts of this case, restoration appears practicable, but the wrong occurring here does not justify the application of mandatory injunctive relief. ${ }^{168}$

Under certain circumstances, then, equitable considerations may simply preclude imposition of a mandatory injunction, and the civil penalty will provide the most satisfactory remedy for resolving the case. Situations in which unauthorized work would have been permitted if application had been made in advance, ${ }^{169}$ where restoration would do more harm than good, ${ }^{170}$ or where a violation has already been vindicated under state law $^{171}$ are illustrative.

Unfortunately, the civil penalty is unavailable as relief in many of the contexts in which it could be most useful. Unlike the Rivers and Harbors Appropriation Act of 1899, the FWPCA does not necessarily prohibit the building of unauthorized structures. ${ }^{172}$ As a result, civil penalties may have

167. The bulkhead extended out beyond the mean high water mark of a navigable sound, and after it was constructed, the area which it confined was filled. As is frequently the case, the work violated both sections 10 and 13 of the 1899 Act as well as the FWPCA: the bulkhead was an unauthorized structure under section 10 , and the fill was prohibited as an unauthorized modification of the navigable capacity of the sound. See 1899 Act $\$ 10,33$ U.S.C. $\$ 403$ (1970). Moreover, the fill was both a prohibited discharge of refuse under section 13, 33 U.S.C. $\$ 407$ (1970), and an unlawful discharge of a pollutant under section 301(a) of the FWPCA, 33 U.S.C. $\S 1311$ (a)(Supp. IV 1974). All potential bases for relief were alleged in the complaint.

168. No. 75-0008-CIV-7, slip op. at 8 (E.D.N.C. Apr. 14, 1976).

169. See note 115 supra and accompanying text.

170. See note 123 supra and accompanying text.

171. See notes 205-08 infra and accompanying text.

172. See note 79 supra and accompanying text. 
only limited value as an instrument for enforcing federal control over that type of activity.

In sum, a variety of remedies is available to the government when it seeks judicial enforcement of the restrictions on land and water resource use which have been created by the Rivers and Harbors Appropriation Act of 1899 and the Federal Water Pollution Control Act Amendments. Unauthorized activities frequently fall within the scope of both statutes, thereby increasing the range of available remedies. ${ }^{173}$ When he files his complaint, the United States Attorney may pray for all the relief in his arsenal, but within this broad prayer there is normally some particular remedy or combination of remedies that best satisfies the interests of the overall federal regulatory program. In short, there is usually a difference between the relief which the prosecutor is seeking and the relief he expects to obtain. An early and accurate assessment of realistic expectations for relief will enhance the possibility of settling the case and will shorten the time consumed at trial if efforts to compromise should fail. ${ }^{174}$ The final section of this Article will deal with the problem of identifying the most appropriate remedy for particular types of cases. In particular, the discussion will revolve around what is perhaps the single most effective remedy available to the government-the mandatory injunction requiring restoration.

\section{ENFORCING THE PROVISIONS OF THE 1899 ACT AND THE FWPCA: THE AVAILABILITY OF MANDATORY INJUNCTIVE RELIEF}

The most common type of legal proceeding to enforce provisions of the 1899 Act or the FWPCA is a civil action for equitable relief against the owner of the property upon which the unauthorized activity has occurred. In theory, any party participating in a violation, such as a lessee or a contractor, may be joined as a party defendant and held civilly liable, ${ }^{175}$ but restoration of an area can probably be demanded only of the owner. If a party other than the owner were the object of a restoration order, the result would be a court-ordered trespass to land, the propriety of which is obviously subject to question. ${ }^{176}$

173. For example, see note 167 supra and accompanying text.

174. In United States v. Golden Acres, No. 76-0023-CIV-4 (E.D.N.C. Jan. 13, 1977), the defendant stipulated to liability and also that restoration was the most appropriate remedy for the fill areas which he still owned. The only issue that had to be tried was the appropriate remedy for that portion of the fill area which had changed ownership. The trial took less than three hours. See notes 120-22 supra for a further discussion of the case.

175. See, e.g., United States v. Perma Paving Co., 332 F.2d 754 (2d Cir. 1964)(lessee liable for creating obstruction to navigation). For the proposition that an owner may be vicariously liable for unauthorized work performed by his contractor, see United States v. Arnett, No. 75-0008-CIV-7 (E.D.N.C. Apr. 14, 1976), and the discussion thereof at notes 166-68 supra and accompanying text.

176. $C f$. United States v. Golden Acres, Inc., No. 76-0023-CIV-4, slip op. at 7 (E.D.N.C. 
While civil actions involving water resource uses are normally brought by the federal government, it should be emphasized that the United States is not the only potential plaintiff in such cases. There may also be other parties whose interests are closely allied with those of the United States and who may have claims against a property owner performing unauthorized work. For example, the work might result, either directly or indirectly, in a trespass to the land of another private owner. In addition, many states have regulatory programs that are comparable to those of the federal government, ${ }^{177}$ or claim title to submerged and tidal lands within their boundaries. ${ }^{178}$ Thus, an unauthorized filling of submerged lands could result in liability to the United States under the Rivers and Harbors Appropriation Act of 1899 and the FWPCA, ${ }^{179}$ to the state or to a private owner of submerged lands in trespass, and to the state under its water resource protection laws. Although state or private claims may, in some cases, support a mandatory injunction for removal of the fill, ${ }^{180}$ these other parties may have difficulty in asserting those claims within the context of a federal enforcement action. The extent to which either the 1899 Act or the FWPCA creates a federal cause of action for states or private parties is very unclear. ${ }^{181}$ and if a district court should lack federal question jurisdiction over

Jan. 13, 1977)(court refused to order restoration after defendant had sold property to innocent purchasers), discussed at notes 120-21 supra and accompanying text.

177. For example, N.C. GEN. STAT. § 113-229 (1975) (amended 1975), creates a state regulatory program which is roughly comparable in scope and application to the federal program under section 404 of the FWPCA, 33 U.S.C. $\$ 1344$ (Supp. IV 1974). Failure to obtain requisite state permits can form the basis for either criminal or civil proceedings. N.C. GEN. STAT. $\S \S$ 113-229(k) and $(l)$ (Supp. 1975). See also Georgia Water Quality Control Act, GA. CoDE ANN., ch. 17-5, §§ 17-501 et seq. (1971); Illinois Environmental Protection Act, Title III: Water Pollution, ILl. ANN. STat. ch. 111 1/2, $\$ 11011$ et seq. (Smith-Hurd Supp. 1977).

178. The State of North Carolina claims title to submerged lands up to the mean high water mark. See Carolina Beach Fishing Pier, Inc. v. Carolina Beach, 277 N.C. 297, 303, 177 S.E.2d 513, $516(1970)$. The State Land Act of 1959 provides that land under navigable waters, i.e., submerged lands up to the mean high water mark, cannot be conveyed in fee but that easements can be granted. N.C. GEN. STAT. § 146-3 (1974). See also S.C. CONST. art. XIV.

179. An unauthorized fill project normally violates sections 10 and 13 of the 1899 Act, 33 U.S.C. $\S \S 403,407$ (1970), and may violate FWPCA $\$ 301$, 33 U.S.C. $§ 1311$ (a)(Supp. IV 1974). See United States v. Arnett, No. 75-0008-CIV-7 (E.D.N.C. Apr. 14, 1976), discussed at notes 166-68 supra and accompanying text.

180. See, e.g., O'Neal v. Rollinson, 212 N.C. 83, 192 S.E. 688 (1937); cf. State v. Brooks, 279 N.C. 45,181 S.E. $2 d 553$ (1971) (injunction not granted).

181. Opinions on the extent to which the Rivers and Harbors Appropriation Act of 1899 creates a federal cause of action for private plaintiffs vary widely among the circuits. Some hold that the Act's remedies are available only to the federal government and that private parties must look to state law for relief against work performed in navigable waters. See, e.g., Red Star Towing \& Transp. Co. v. Department of Transp., 423 F.2d 104 (3d Cir. 1970). See also Lavagnino v. Porto-Mix Concrete, Inc., 330 F. Supp. 323, 325-26 (D. Colo. 1971)(court's view appears to be that private actions are "limited to actions for injury in the use of navigable waters for the purposes of navigation"). The Fifth Circuit's position is unclear. Compare Bass Anglers Sportsman Soc'y v. United States Steel Corp., 324 F. Supp. 412 (N.D., M.D. and S.D. Ala.), aff'd sub nom. Bass Anglers Sportsman Soc'y v. Koppers Co., 447 F.2d 1304 (5th Cir. 
the particular claims of a state or private owner, their presence as plaintiffs in enforcement proceedings would have to be supported by some other basis for subject matter jurisdiction. ${ }^{182}$

Assuming that appropriate parties are before the court, few substantive legal issues presently remain as to either the reach of federal jurisdiction or the extent of liability under the 1899 Act or the FWPCA. ${ }^{183}$ In general, both acts are currently viewed as absolute liability statutes. ${ }^{184}$ In actions brought under the 1899 Act, the government normally must show only that the unauthorized work occurred below the mean or ordinary high water mark of some navigable water body in order to establish both jurisdiction and liability. If this fact is not obvious from the nature of the disputed work, a field survey may have to be conducted to establish the mean high water mark with reference to the property in question. While this may be timeconsuming, it rarely presents serious technical difficulties. ${ }^{185}$ As for viola-

1971), with Neches Canal Co. v. Miller \& Vidor Co., 24 F.2d 763 (5th Cir. 1928). Case law from the Fourth, Eighth and Ninth Circuits seems to indicate that a private action may be maintained under the 1899 Act upon a showing that a particularized injury to the plaintiff has resulted from the unauthorized activities. See James River \& Kanawha Canal Parks, Inc. v. Richmond Metropolitan Auth., 359 F. Supp. 611, 639, aff'd per curiam, 481 F.2d 1280 (4th Cir. 1973); Sierra Club v. Morton, 400 F. Supp. 610, $622-25$ (N.D. Cal. 1975); Hawkinson v. Blandin Paper Co., 347 F. Supp. 820,823 (D. Minn. 1972)(court tacitly assumes plaintiff's recovery is possible on a proper showing of injury but denies relief on the facts). This point does not appear to have been litigated under the FWPCA.

182. Assuming that the requisite jurisdictional amount is in controversy, either a state or private party should be able to maintain a federal diversity action based on state law against a non-resident land owner. See 28 U.S.C. $\$ 1332$ (1970). In certain circumstances, a state or private litigant might also be able to invoke a federal court's admiralty or maritime jurisdiction. See id. $\$ 1333$.

183. See notes $65-72,80-88$ supra and accompanying text for a discussion of jurisdiction under the Acts.

184. Although the absence of negligence or intent may be a consideration in fashioning the appropriate remedy, see notes 166-68 supra and accompanying text, there is not even a suggestion in the case law that the government is required to show that unauthorized work was intentional or negligent in order to be entitled to civil relief under either the 1899 Act or the FWPCA. Even the criminal provisions of the 1899 Act are generally acknowledged to contemplate absolute liability. See note 129 supra and accompanying text. The only occasion where the government clearly is required to prove negligence or intent is where it proceeds criminally under the FWPCA. See FWPCA § 309(c) 33 U.S.C. \& 1319(c) (Supp. IV 1974).

185. See generally W. Johnson, D. Jessup \& P. CampBell, Layman's Guide to Investigating Section 10 Violations 9-14 (1975)(Land and Natural Resources Division, Department of Justice). The normal procedure is to obtain tide gauge readings in the vicinity of the unauthorized work in order to establish the elevation of the mean high water mark in relation to mean sea level. This information is normally quite readily available from the Department of Commerce, which maintains tide gauges at frequent intervals along the coast. A survey party then projects the elevation of the mean high water mark horizontally onto the property in question and marks its limit with stakes.

The procedure is somewhat more complicated in the case of an unauthorized fill, since the original elevation and contour of the property has been altered. The procedure here is to establish the mean high water mark on each side of the fill by the method described above. In simple cases, a straight line can be drawn between the two points. Where a straight line does not 
tions of the FWPCA, the relevant inquiry is whether the area in question is "periodically inundated" and is characterized by certain types of vegetation normally associated with the periodic presence of saline, brackish or fresh water. ${ }^{186}$ In a majority of cases, these two elements can be proved by conducting a biological inventory of the disputed property and by projecting predicted tide elevations onto the area in question by means of a field survey. ${ }^{187}$

Recent case law suggests that future litigation under the 1899 Act and the FWPCA may be concerned primarily with questions relating to remedies. Of all the remedies available for enforcing federal restrictions on private activities in American waters and wetlands, the mandatory injunction requiring restoration of the unauthorized work to the status quo ante is probably the most effective. The burdens which restoration places on the defendant create a significant deterrent and ensure that he will not enjoy any benefits of his unauthorized work. ${ }^{188}$ Restoration also gives the federal government physical control over the navigability or quality of the affected waters. Another advantage of the mandatory injunction which is often overlooked is the role that remedy plays in protecting public water resource rights from gradual encroachment. A single unauthorized project may cause no appreciable harm to navigability or water quality by itself, but when it is considered together with other similar projects, the cumulative impact may be considerable. ${ }^{189}$ The danger in allowing small and relatively insignificant violations to remain in place is that they will most likely proliferate, and that developing case law may someday preclude efforts to deal effectively with the cumulative impact problem. 190

appear to provide a reasonable approximation, aerial photographs of the area taken before the work was commenced normally reveal a vegetation line coinciding quite closely with the mean high water mark. Scale aerial photographs of most coastal areas are taken at relativcly frequent intervals by the Department of Agriculture's Agricultural Stabilization and Conservation Service.

186. See notes 73-88 supra and accompanying text.

187. The process would be similar to the one described in note 185 supra, except that the elevation of the highest predictable annual tide could be used in place of the elevation of the mean high water mark. The National Oceanic and Atmospheric Administration publishes annual tide tables for the entire United States, and this information can normally be used to compute the highest predictable tide in a particular locality.

188. In fact, restoration in certain situations may be so burdensome that a court may decline to grant that remedy on equitable grounds. See notes 191-95 infra and accompanying text.

189. One small pier standing alone on the bank of a navigable river would probably have an insignificant effect on the public interest. On the other hand, a small pier standing every fifty feet along both banks of the river would effectively deprive the public of its full use of the federal government's navigational servitude. The question arises whether this is not also a problem even where the piers are authorized by the Corps of Engineers. In the future, considerable administrative and judicial effort may be devoted to determining the "saturation points" for various types of structures and activities.

190. United States v. Venters Holding Co., Civil No. 986 (E.D.N.C. June 26, 1974), 
Despite the clear advantages of the mandatory injunction in federal water resource protection, a group of decisions from the Fifth Circuit clearly indicates that this remedy will not be routinely available. In reversing mandatory injunctions entered by the trial courts in United States $v$. Joseph G. Moretti, Inc., ${ }^{191}$ United States v. Sexton Cove Estates, Inc. ${ }^{192}$ and Weiszmann v. District Engineer, ${ }^{193}$ the court of appeals held that a remedial injunction could not be granted under the federal water resource statutes without the prior development of a factual record which established that the choice of remedy was based on a complete examination of the circumstances, practicalities and equities of the particular case. ${ }^{194}$ According to the court, restoration should not be ordered without first giving the defendants "an adequate opportunity before the district court to adduce evidence and present their contentions with respect to the restoration issue." 195

An examination of the case law discloses a number of different factors which might influence a court to limit the availability of mandatory injunctive relief. Some have been mentioned earlier in this discussion. For example, United States v. Golden Acres, Inc. ${ }^{196}$ suggests that restoration may be unavailable where title to the disputed property has passed into the hands of innocent purchasers. ${ }^{197}$ The Fifth and Ninth Circuits have both indicated that restoration might also be inappropriate where its cost would be an unreasonable burden for the defendant to bear or where it would be technologically infeasible to return the area to the status quo ante. ${ }^{198}$ Still another limiting factor might exist where restoration, though practicable, could cause greater harm to the environment or to other national interests than allowing the work to remain in place. ${ }^{199}$

The equities of the government's position may also affect a court's decision whether to order restoration. Although a number of cases indicate

presents a useful example of a situation in which a mandatory injunction was appropriate to prevent a violation from growing to such an extent that it could no longer be controlled. The case involved an addition to a restaurant. Constructed on pilings, the addition extended out some seven feet beyond the high water line of a navigable river. See id., slip op. at 3 . While it seems clear that the seven foot extension did not create any real danger to navigation or the environment, see id. at 2, the district court nevertheless required the removal of the seven feet of the addition. Id. at 3-4. The court seemed cognizant of the fact that allowing that intrusion on navigability could make it difficult to enjoin similar future violations.

191. 526 F.2d 1306 (5th Cir. 1976).

192. 526 F.2d 1293 (5th Cir. 1976).

193. 526 F.2d 1302 (5th Cir. 1976).

194. 526 F.2d at $1310 ; 526$ F.2d at $1301 ; 526$ F.2d at 1304.

195. United States v. Sexton Cove Estates, Inc., 526 F.2d at 1301; accord, United States v. Joseph G. Moretti, Inc., 526 F.2d at 1310.

196. No. 76-0023-CIV-4 (E.D.N.C. Jan. 13, 1977).

197. See notes 120-122 supra and accompanying text.

198. See United States v. Sexton Cove Estates, Inc., 526 F.2d 1293, 1301 (5th Cir. 1976);

United States v. Sunset Cove, Inc., 514 F.2d 1089, 1090 (9th Cir. 1975).

199. For an example, see note 123 supra. 
that neither laches nor estoppel may be raised to bar the government from bringing an enforcement action, ${ }^{200}$ such factors as misbehavior, delay or other prejudicial actions by government officials appear to be appropriate considerations in fashioning a final decree. ${ }^{201}$ Failure by the Corps of Engineers to follow its own regulations in handling a violation may also affect the remedy. In the earlier of its two Moretti decisions, ${ }^{202}$ the Fifth Circuit vacated the district court's restoration order and remanded the case because the Corps of Engineers had failed to follow a regulation which afforded a violator the opportunity to apply for an after-the-fact permit for its unauthorized work. ${ }^{203}$ This particular pitfall has been cured by a change in regulations, ${ }^{204}$ but other similar breakdowns in the administrative process might well form a basis for postponing or denying mandatory injunctive relief.

The extent to which remedies have already been imposed on the defendant in state court proceedings may also be a pertinent consideration in determining the appropriate federal remedy. As noted earlier, state proprietary and regulatory interests may exist concurrently with federal interests in the nation's waters and wetlands. ${ }^{205}$ Thus, certain unauthorized activities may result in both federal and state judicial enforcement proceedings. If federal regulatory interests have been totally vindicated in state court, it would seem both unnecessary and inequitable to impose any federal remedy. ${ }^{206}$ Even if federal interests have only been partly served by the relief awarded in state court, the earlier result may influence the federal court's

200. E.g., Weiszmann v. Distriet Eng'r, 526 F.2d 1302, 1305-06 (5th Cir. 1976); United States v. Sunset Cove, Inc., 5 E.R.C. 1023, 1028 (D. Ore. 1973), aff'd in part, modified in part, 514 F.2d 1089 (9th Cir. 1975).

201. See Weiszmann v. District Eng'r, 526 F.2d 1302, 1306 (5th Cir. 1976); United States v. Sunset Cove, Inc., 5 E.R.C. 1023, 1028-29 (D. Ore. 1973); United States v. Lewis, 355 F. Supp. 1132, 1142 (S.D. Ga. 1973).

202. United States v. Joseph G. Moretti, Inc., 478 F.2d 418 (5th Cir. 1973), vacating in part 331 F. Supp. 151 (S.D. Fla. 1971).

203. See 478 F.2d at 424-25, 430-32. 33 C.F.R. $\$ 209.120$ (c)(1)(iv)(a)(i)(1972) provided that a District Engineer was authorized to entertain an application for a permit for work already completed "where the necessary primary authority, State or Federal as the case may be, validly exists, when the work was innocently constructed, and where there is no objection to the work."

204. 33 C.F.R. $\$ 209.120(\mathrm{~g})(12)(\mathrm{ii})(\mathrm{b})$ (1976) now provides that:

If criminal and/or civil action is instituted against the responsible person, the District Engineer shall not accept for processing any application until final disposition of all judicial proceedings, including the payment of all prescribed penalties and fines and/or the completion of all work ordered by the court.

205. See notes 177-78 supra and accompanying text.

206. For example, if the violation clearly involved work that would have been permitted if application had been made in advance, a relatively modest civil penalty might be appropriate relief. If the defendant had previously been fined in state court for the same work, the amount of the fine would seem to be a factor which the federal court might wish to consider in calculating the amount of a civil penalty. 
choice of remedy. In United States $v$. Arnett,${ }^{207}$ for example, the district court cited an earlier state criminal conviction and fine as one of several reasons for imposing a civil penalty in lieu of restoration. ${ }^{208}$

Unfortunately, while Sexton Cove and its companion cases seem to call for greater judicial attention to the remedial aspects of enforcement litigation, the Fifth Circuit made no real attempt to fashion a general test for determining whether mandatory restoration orders are appropriate nor has it set forth in any detail the matters which district courts should consider before choosing a remedy. ${ }^{209}$ Undoubtedly, the wide variety of possible factual situations in which enforcement actions may arise complicates judicial efforts in this direction. One approach, however, might be to begin with the general principle that restoration is presumptively the most effective and therefore the most appropriate civil remedy for violations of the 1899 Act and the FWPCA. The problem then becomes one of identifying the situations in which restoration is inappropriate. Once an exception to this general rule has been identified, the actual grounds for denying a mandatory injunction will frequently suggest the most suitable alternative remedy for the case. For example, if the reason for denying restoration is that the defendant lacks the means or expertise to perform it competently, then permitting the government to restore the area and making the defendant liable for restitution would seem to be the best alternative to a remedial injunction. ${ }^{210} \mathrm{Or}$, if restoration is withheld because the work would have been permitted if proper authorization had been requested in advance, then the objective of the remedy would be to deter others from bypassing the administrative process, and a moderate civil penalty would seem to satisfy the federal regulatory interest. In a case where the violation is serious but restoration is impossible or impractical, a heavy civil penalty, calculated to deprive the defendant of any gain from his unauthorized work, may be the best solution. ${ }^{211}$ In short, selecting the most suitable remedy in actions to enforce the Rivers and Harbors Appropriation Act of 1899 and the Federal Water Pollution Control Act Amendments of 1972 will become a relatively easy task once the courts have clearly defined the factual settings in which restoration is inappropriate.

207. No. 75-0008-CIV-7 (E.D.N.C. Apr. 14, 1976).

208. Id. slip op. at 8-9.

209. See the cases cited in notes 191-95 supra. In each of the three cases, the court of appeals did not suggest how or even whether the district courts' original restoration orders should be affected by the proceedings on remand. The mandate was simply for the lower courts to develop a more complete record in the remedial aspect of the proceedings.

210. See notes 153-64 supra and accompanying text.

211. See note 122 supra. 


\section{CONCLUSION}

Under the commerce clause, the federal government has broad powers to control the use of the country's water resources. No longer content to restrict that power to the protection of water transportation, Congress and the executive branch have, with the courts' approval, sought in recent years to guarantee the public a broad spectrum of rights in the nation's water resources. Both the Rivers and Harbors Appropriation Act of 1899 and the 1972 Amendments to the Federal Water Pollution Control Act seek to protect these rights by restricting inconsistent land and water resource uses.

In effect, the 1899 Act and the FWPCA burden submerged and riparian lands with a federal water resource servitude. The federal government has a broad range of remedial instruments at its.disposal in seeking to secure and protect public rights over navigable waters and submerged and riparian lands. But the enforcement task is extremely complex. It is complicated by a variety of policy considerations; fairness, judicial economy and administrative efficiency are only a few. In order to maximize each of these interests, efforts to enforce water resource legislation should begin with the administrative process. Additional legislation is needed to provide the appropriate agencies with the remedial instruments which are required for effective enforcement. Administrative civil penalties, administrative restoration and cease-and-desist orders, and self-help procedures should all be considered.

The courts should have to be concerned with enforcing federal controls on water resource use only when the administrative process is being defied or when fairness requires that a case be adjudicated by a neutral body. The range of judicial remedies presently available to enforce the provisions of the 1899 Act and FWPCA is broad enough to enable the courts to arrive at a just result im a majority of cases. But, for enforcement to be effective, these remedies must be applied in a consistent and programmatic manner. Unfortunately, no general principles or standards have yet been adopted to guide the application of particular remedies to particular cases. One approach might be to establish the renedial injunction as the preferred remedy in cases involving water resource violations and to direct future efforts toward defining appropriate exceptions to this general rule. Such an approach would promote equity and uniformity without unnecessarily restraining judicial flexibility. Whether it is this test or another is unimportant. The crucial point is that some coherent approach must be established soon. The water resource enforcement process has matured a great deal in recent years, and its future growth and effectiveness will depend largely on the guidance it receives from the courts. 